\title{
Articles of Association in UK Private Companies: An Empirical Leximetric Study
}

\author{
Jonathan Hardman ${ }^{1}$ (D)
}

Accepted: 26 April 2021 / Published online: 19 May 2021

(C) The Author(s) 2021

\begin{abstract}
The final provisions of the UK's Companies Act 2006 have now been in force for 10 years. Part of this regime included a new form of model constitution, known as the Model Articles. This article uses empirical data to establish whether the Model Articles have been used in practice or not. To do so, it tracks the constitutions of a sample of companies (those incorporated in Scotland in October 2009) from their incorporation until December 2017. It undertakes a leximetric methodology to code 12 variables across the constitutions, with a 0 being coded for convergence to the default regime and 1 being coded for divergence from the default regime. The results show that the majority of companies do not deviate from the default regime, other than in one respect: most allowed for the ability to appoint alternate directors. More importantly, however, the dataset shows that few of the sample companies amended their articles of association following incorporation, and that there is a strong correlation between certain coding patterns and the presenter, or formation agent, used to incorporate the company.
\end{abstract}

Keywords Company law $\cdot$ Corporate law $\cdot$ Leximetrics $\cdot$ Empirical methodology

\section{Introduction}

It has now been 10 years since the final provisions of the UK Companies Act 2006 were brought into force. ${ }^{1}$ One of the provisions that was introduced was a new system for incorporating companies. ${ }^{2}$ The new system was incredibly similar to the old

\footnotetext{
1 The final transitional provisions, Companies Act 2006 (Commencement No. 8, Transitional Provisions and Savings) Order 2008 (SI 2008/2860), became effective on 1 October 2009. See Hardman (2020a).

2 Companies Act 2006, s. 9 replaced Companies Act 1985, s. 10 and Sch. 1.

Jonathan Hardman

Jonathan.hardman@ed.ac.uk

1 Lecturer in International Commercial Law, University of Edinburgh (School of Law),

Edinburgh, UK
} 
system. In particular, UK company law left a large amount of corporate law contained in the constitution of the company rather than in statute, ${ }^{3}$ with the articles of association the key constitutional document. ${ }^{4}$ This voluntary approach has often proved controversial. ${ }^{5}$ To assist those who cannot or do not want to incur the cost of drafting a bespoke constitution the UK government lays out default rules which apply in the absence of contrary agreement. ${ }^{6}$ Prior to the implementation of the Companies Act 2006 these default articles were known in the UK as 'Table A', 7 and since the implementation are now the 'Model Articles'. ${ }^{8}$ Thus the Model Articles provide the default regime for company constitutions in the UK for all companies incorporated since 1 October 2009 . The UK adopts a slightly unusual approach, in that should a company elect to apply the default rules, any change in the default rules will not result in any change to such company's articles of association: such an election only applies the articles of association as at the date of incorporation, not from time to time. ${ }^{9}$ There has only been one minor change to the Model Articles since their introduction, ${ }^{10}$ but the content of the Model Articles varied greatly from that in Table A. ${ }^{11}$ Accordingly, the change on 1 October 2009 from Table A for new companies to the Model Articles represented somewhat of a break in continuity for UK company law. This article explores how the market has re-acted to the introduction of the Model Articles.

This article focuses on private companies. There are a number of reasons to do so. Firstly, a company is a private company by default in the UK. ${ }^{12}$ This makes them the core company entity within the UK corporate law framework. This is reflected by the number of legal vehicles_-as at 2015, while there were in excess of three million companies on the UK companies register, only around 7,500 were public companies, with the vast majority being private. ${ }^{13}$ Secondly, private companies play a key role in UK business. It is sometimes stated that private companies are, as a rule, associated with smaller companies while public companies are seen to denote

\footnotetext{
${ }_{3}$ For example, see Chiu (2009), p 697; Davies and Worthington (2016), para. 3-13; Omar (2009).

${ }^{4}$ Companies Act 2006, ss. 17-18.

${ }^{5}$ For example, see the critique of leaving the division of powers between shareholders and directors to the company's constitution in Watson (2011).

6 Companies Act 2006, s. 20.

7 Companies Act 1985, s. 8.

8 Companies Act 2006, s. 19; The Companies (Model Articles) Regulations 2008 (SI 2008/3229). There are, actually, three sets of Model Articles: for private companies limited by share (Schedule 1), for private companies limited by guarantee (Schedule 2) and for public companies (Schedule 3). In line with the approach taken generally in this article, we shall only look to the first of these three, and shall refer to those listed in Schedule 1 (and only them) as the Model Articles throughout this article. Any reference to a 'Model Article' is a reference to the corresponding article of Schedule 1 of these regulations.

9 Riley (2010).

10 Minor changes were enacted to omit removal of directors on mental health grounds by the Mental Health (Discrimination) Act 2013, s. 3.

11 See Department for Business Innovation and Skills (2011) for a full discussion of the differences between Table A and the Model Articles.

12 Companies Act 2006, s. 4(2).

13 Davies and Worthington (2016), para. 1-23.
} 
larger companies. ${ }^{14}$ However, many larger UK companies are structured as private companies, ${ }^{15}$ and private companies are used structurally in several industries, most notably in private equity. ${ }^{16}$ Private companies are, therefore, important commercial vehicles in their own right, in addition to being the first step towards having a public company. Thirdly, while considerable research has been undertaken into public companies, ${ }^{17}$ private companies remain under-analysed and they are therefore ripe for study. This means that a study of private companies fills an important gap in corporate law literature.

The purpose of this article is, therefore, to explore these Model Articles for private companies within the UK. To do so, it firstly establishes what the Model Articles were meant to achieve in terms of default rule literature. It identifies that the Model Articles were intended to be a 'majoritarian default', that is reflecting the norms that the majority of market participants would have picked were they to do have done so. It then moves to explore whether this is the case: are market participants in the UK actually using the Model Articles in practice or not? To test this, it adopts a leximetric methodology ${ }^{18}$ to code the articles of association of a sample of companies incorporated since the Model Articles replaced Table A. This methodology has been historically used to judge whether laws are friendly towards a certain group or not, including over time, and more recently to establish compliance with law. This article is the first article to apply this methodology to convergence between market activity and default rules. It is also the first to holistically review a sample of articles of association under the new regime to establish whether the Model Articles are, ultimately, correct. It is therefore novel in both its methodology and the subject matter of its study. Each of these have important implications: the former means that this methodology can be exported to establish whether other default rules, across a myriad of subjects, are actually used or not-a new method of examining the content of default rules; the latter enables us to explore the previously-ignored subject of whether the statutory default rules are followed in practice or not.

The results of this novel methodology show that the majority of variables are not frequently deviated from. 11 of the 12 variables selected show high levels of convergence to the default rules. However, the majority of companies did provide

\footnotetext{
14 For example, see Cosh and Hughes (1994), p 18.

15 For example, see Ferran (2019), pp 527-528.

16 Berry (2019).

17 For example, Kraakman et al. (2017), ch. 8 (Control Transactions) relates exclusively to control transactions in listed companies. Similarly, in Berle and Means (1967), the modern theory that company law exists to deal with the separation of ownership and control arose in the context of US listed companies. Bainbridge (2008), p 12 acknowledges that his 'director primacy' theory is effectively a theory for public companies only.

18 Cooter and Ginsburg (2003).
} 
for the ability for private companies to appoint alternate directors, which the Model Articles do not provide. Further study of the patterns of divergence, however, reveal two additional factors: firstly, it was unusual for companies to change their articles of association. Secondly, the presenter who presented the company for registration $^{19}$ seems to be a driving factor for combination of convergence or divergence from the default rules. This may tell us that more attention should be paid to presenters of companies: at the moment, the UK government suggests to those wishing to form companies that they may wish to use a presenter, and provides a list of those it understands are active in the presenter market. ${ }^{20}$ However, if presenters are a key driving factor in the articles of association of the company, and market participants are not varying their articles of association post-incorporation, then it may be that presenters are more important in the corporate governance regime than are acknowledged.

There are limits to what this study can conclusively prove. In particular, questions can be raised as to the sample selection, variable selection, the coding of those variables, and the meaning of the analysis. These questions can, however, all be answered to a sufficient degree to highlight some importance to the substantial outcome of this study in addition to the methodological developments. The methodology also has considerable potential for further expansion and study.

This article proceeds as follows. Section 2 reviews default rule theory and applies it to the articles of association in the UK. Section 3 outlines the methodology utilised in this paper, including the leximetric approach, sample selection, and coding selection. Section 4 outlines the results of the application of this methodology to publicly available documents. Section 5 discusses the implications of the results, explores potential critiques of the approaches taken in this article, and discusses potential for further study. Section 6 concludes.

\section{Articles of Association and Default Rules}

\subsection{Importance of Articles of Association}

A UK company's core constitutional document is its articles of association. ${ }^{21}$ It has been stated that 'a remarkable feature of British company law is the extent to which it leaves regulation of the internal affairs of a company to the company itself through rules laid down in its constitution, in particular in its articles of association'. ${ }^{22}$ This includes the balance of powers between the board of directors and shareholders, ${ }^{23}$ which has been described by the New Zealand Law Commission as

\footnotetext{
19 A presenter is a third party who is paid by those wishing to incorporate their company to assist with the incorporation process. See Davies and Worthington (2016), para. 4-32.

${ }^{20} \mathrm{See}$ https://www.gov.uk/government/publications/formation-and-company-secretarial-agents/compa ny-formation-agents-and-secretarial-agents.

21 Companies Act 2006, s. 17(a).

22 Davies and Worthington (2016), para. 3-13.

23 Automatic Self-Cleansing Filter Syndicate Co v. Cuninghame [1906] 2 Ch 34 CA; Shaw \& Sons (Salford) Ltd v. Shaw [1935] 2 KB 113. For criticism of this approach, see Watson (2011).
} 
'entirely unsatisfactory' and 'an anachronism which is misleading, ${ }^{24}$ Regardless of the criticisms of the approach, the UK has left a large amount of corporate law to be decided in each company's constitution since $1856 .{ }^{25}$ When adopting the Companies Act 2006, the UK government decided not to "change the principle'26 of matters left to constitutions, and such constitutions being default rules. In doing so, it tried to maintain the policy objective of 'thinking small first', by keeping the Model Articles as 'simple as possible' to meet the 'needs of small, owner-managed businesses'. ${ }^{27}$ The rationale for this was that they should 'focus on the requirements of the small businesses which make up the majority of this class of company, rather than the minority of such companies whose needs are more complex'. ${ }^{28}$ Articles of association, therefore, remain able to be chosen by shareholders on incorporation, ${ }^{29}$ or amended thereafter. ${ }^{30}$ If bespoke articles of association are not chosen, then the Model Articles will apply. ${ }^{31}$ This makes the Model Articles default rules.

A large number of companies use formation agents in respect of their formation, also known as presenters. ${ }^{32}$ Davies and Worthington have stated of these presenters that:

the promoters must determine the extent to which the appropriate model is ousted or adopted (whether explicitly or by default). Company formation agents normally have their own standard forms, which formally exclude the model altogether, though these standard forms are themselves typically developed from the statutory model and its predecessors. The other extreme, the option of not registering any articles and relying on the mode, is rarely chosen because most companies wish to define their own rules. ${ }^{33}$

As the Model Articles apply unless market participants choose otherwise, they are opt-out, or default, rules. Considerable literature has been dedicated to default rules. Some scholars have debated whether they are of relevance at all. This is based on the Coase Theorem, that in the absence of transaction costs, default rules are irrelevant and an efficient outcome will arise anyway. ${ }^{34}$ This can be divided into a 'hard' version of the theorem, that parties will reach a Pareto Optimal ${ }^{35}$ outcome regardless of default rules, and a 'soft' version of the theorem, that the default rules in question

\footnotetext{
24 New Zealand Law Commission (1989), paras. 155-156.

25 Watson (2011), pp 605-606.

26 Department for Trade and Industry (2007), para. 3.14.

27 Department for Trade and Industry (2007), para. 3.26.

${ }^{28}$ Department for Trade and Industry (2007), para. 3.27.

29 Companies Act 2006, s. 18(2).

30 Companies Act 2006, s. 21.

31 Companies Act 2006, s. 20(1).

32 See the list of company formation agents proposed by the Government at https://www.gov.uk/gover $\mathrm{nment} /$ publications/formation-and-company-secretarial-agents/company-formation-agents-and-secre tarial-agents.

33 Davies and Worthington (2016), para. 4-32.

34 Coase (1960); Schwab (1989).

35 That is to say, an outcome from which no party can be made better off without making another party worse off. See Feldman (1998).
} 
do not affect the efficiency of the outcome that would have been achieved. ${ }^{36}$ Each version is predicated on the idea that default rules do not matter because in a totally frictionless market, the parties will bargain away any default legal allocation of risk between them. However, even when initially raising the principle, Coase claimed that a world without transaction costs was unrealistic. ${ }^{37}$ It could be said that a world without transaction costs would provide unintended and unexpected consequences to all transactions. ${ }^{38}$ Transaction costs are usually quite high in any given scenario, ${ }^{39}$ and so the world of the Coase Theorem does not exist. Indeed, Coase's initial analysis has been adapted in ways which Coase did not intend-he wanted to flag the importance of transaction costs rather than minimise their role. ${ }^{40}$

There is a corollary of the Coase Theorem: that in a world with transaction costs (i.e. the real world), legal allocation of risk by default rules affects the efficiency of the ultimate bargains struck between the parties. ${ }^{41}$ Indeed, knowledge of the content of the underlying default rules itself is, ultimately, a transaction cost that will feed into this analysis. ${ }^{42}$ As a result, we can say that default rules are of importance to bargains struck, and therefore should be 'correct'. The question then becomes how to pick correct default rules. It is commonly stated that default rules should 'mimic the market' and produce laws that those in the market would have made on the grounds that these are the most efficient. ${ }^{43}$ This is known as a 'majoritarian default'. The logic is that a majoritarian default (in the context of a contractual term) will be:

the meaning that most parties to [...] contracts would use, which will often be the same as the customary meaning or trade usage. If parties expect that courts will apply a majoritarian default when disputes arise over the meaning of the contract, they will know that most of the time the court will choose the term that maximizes the probability of efficient trade. Accordingly, they would be more willing to enter a contract in the first place, despite high transaction costs, than they would under an alternative rule. Choosing a majoritarian default rule reduces the negative consequences of high transaction costs. ${ }^{44}$

The advantage of a majoritarian default rule is therefore that it would reflect what the market considers to be the appropriate default rule. However, this approach is not universally popular. In situations whereby one party is aware as to a market standard position and the other is not, a majoritarian default rule provides the informed party with no incentive to inform the other party of the true meaning, which may in turn lead to inefficient results. Accordingly, rather than a majoritarian default rule, it is argued that sometimes the law should seek to apply a 'penalty default', being a rule

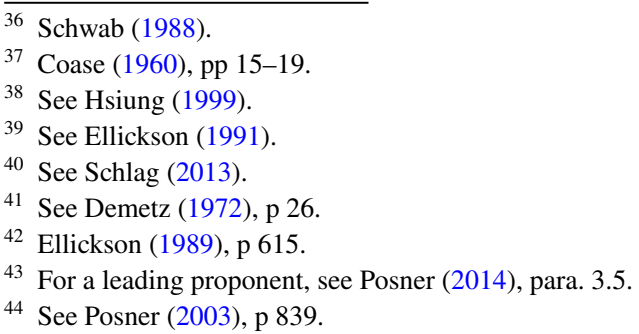


that regular market contractors would not have used. ${ }^{45}$ This logic has been described as:

This strategy, which would give parties an incentive to write a less ambiguous contract than they might otherwise, has two motivations. First, it discourages parties from externalizing the cost of interpreting the contract on the courts. If parties were clearer, courts would have less work to do. Second, it discourages parties from opportunistically concealing information from each other. If one party knows about the ambiguity of the word 'chicken' and prefers the majoritarian meaning, and the other party does not know about the ambiguity, then the first party would have no incentive to disclose the ambiguity to the second, unless a penalty default rule held the informed party to the less favourable meaning. ${ }^{46}$

There is, however, a structural difficulty with penalty rules. An informed party may, even then, decide to proceed with the penalty rather than provide information to the other party which may result in that other party push for a better outcome to a transaction. ${ }^{47}$ This applies even when the party with the information and the party without are on the same 'side' of the transaction. ${ }^{48}$ Supporters of penalty default rules are keen to emphasise that such strategic positioning does not undermine the value of penalty defaults where information asymmetries between the parties are particularly high. ${ }^{49}$ However, their utility in other situations is likely to be limited: it is a question of fact as to whether any given default rule should be a 'majoritarian' or 'penalty' default rule. ${ }^{50}$

In establishing how to set the content of the Model Articles, the UK government chose to design them "with the needs of small, owner-managed businesses in mind'. ${ }^{51}$ Further, they acknowledged that most companies by number are small, and should only need simple articles_-but where needs are more complex, then they are also likely to be more bespoke. ${ }^{52}$ Accordingly, the UK government made certain assumptions about the needs of the majority of companies and set the Model Articles to meet those assumptions. This would appear to be clear majoritarian defaultthe UK government aimed to pick rules that suited the needs of the majority of companies, and therefore that the majority of companies would apply, to save the majority of companies from needing to negotiate their own constitutions. There is certainly no hint of penalty default rhetoric.

But have the UK government picked these correctly? Are market participants actually using the Model Articles, or are they diverging from them? Qualitative

\footnotetext{
$\overline{45}$ See Ayres and Gertner (1989).

46 Posner (2003), p 839.

47 See Johnston (1990); Ayres and Gertner (1991).

48 Adler (1999).

49 Ayres and Gertner (1999).

50 Posner (2003), p 841.

51 Department of Trade and Industry (2007), para. 3.26.

52 Department of Trade and Industry (2007), para. 3.27.
} 
empirical studies of constitutions of UK companies have been undertaken, most notably of constitutions of companies prior to $1850 .{ }^{53}$ We can build on this by providing a quantitative empirical studies of articles of association of companies incorporated in the UK under the Companies Act 2006. We will synthesise large amounts of data by adopting a leximetric approach to analysing articles of association.

\section{Methodology}

\subsection{Methodological Approach}

The rest of this article empirically examines whether participants are adopting the Model Articles as the articles of association for private companies, as a way to evaluate whether the Model Articles achieve the UK government's aims by representing a majoritarian default approach. We achieve this by exploring whether the majority of companies are, in fact, using the Model Articles. To do so, we adopt a quantitative, or leximetric, methodology. The term 'leximetrics' was coined in 2003 by Cooter and Ginsburg ${ }^{54}$ to describe a quantitative analytical style that developed in the late 1990s. Leximetrics is a "quantitative form of empirical methodology'. ${ }^{5}$ Lele and Siems state that: "Leximetrics" can be understood as every quantitative measurement of law'. ${ }^{56}$ The pioneers of this approach were La Porta, Lopez-de-Silanes, Shleifer and Vishny, who in two articles in the late 1990s began the methodological school. ${ }^{57}$ La Porta and others applied scores to laws within various jurisdictions. When comparing these to various financial metrics applicable to that jurisdiction, they were able to draw lines of correlation between aggregate scores for certain legal norms and financial metrics. They therefore selected a series of variables in legal norms and applied coding to allow them to establish correlations between different scores and financial metrics. It is important to note that such correlation does not imply causation. ${ }^{58}$

The approach of La Porta and others, 'has been and is still cited frequently and usually uncritically, in legal as well as economic journals' ${ }^{59}$ Two key strands of criticism emerge: those of variable selection; and those of coding. On the selection of variables, Lele and Siems have stated:

[T] he selection of variables must be intelligible and wide enough to function as a proxy for shareholder protection in general, which is not the case with

\footnotetext{
53 Freeman et al. (2013).

54 Cooter and Ginsburg (2003).

55 Hardman (2017), p 39.

56 Lele and Siems (2007), p 20.

57 La Porta et al. (1998); La Porta et al. (1997).

58 Fagernäs, Sarkar and Singh (2008), p 21.

59 Braendle (2006), p 260.
} 
La Porta et al's eight variables. They do not fully capture the most significant aspects of the law. ${ }^{60}$

It is therefore important to select the variables used within a leximetric data set correctly, especially when trying to use the data (as La Porta et al did) to make more general statements about the legal landscape. Sometimes more variables are required in order to provide a more complete understanding of the issue. ${ }^{61}$ Lele and Siems emphasise the importance of 'functionality' within variables - that legal rules may achieve the same function in ways which appear very different. It is therefore important to ensure that variables are tested functionally rather than by formal appearance. There have been issues raised with how La Porta and others coded their scores within variables. Spamman has found that re-coded data varies greatly from the official La Porta data set. ${ }^{62}$ Similarly, Cools found that the coding ignored various other legal devices to achieve the same ends. ${ }^{63}$ It is therefore important to ensure that the coding is consistently and accurately performed on a functional basis when undertaking leximetric research.

Leximetrics began as a method by which to analyse different legal approaches to shareholder protection and their effects, but has developed considerably. It is widely used in comparative law from testing whether corporate laws converge over time, ${ }^{64}$ to comparisons of collateral and bankruptcy law, ${ }^{65}$ to comparing labour law between jurisdictions. ${ }^{66}$ Such studies have also become more sophisticated in their analysis. Thus, studies have commenced comparing jurisdictions over time ${ }^{67}$ and phenomena within a single jurisdiction over time. ${ }^{68}$ This approach shows the flexibility of a leximetric model: rather than a traditional qualitative analysis, any laws can be subject to a leximetric, quantitative analysis provided that the variables and the coding are correct.

For application to this article, the most important recent development of leximetric methodology occurred in the context of strategic reporting. Esser, MacNeil and Chalaczkiewicz applied a leximetric approach to establish whether companies were complying with strategic reporting requirements. ${ }^{69}$ Rather than variables as to 'law' being coded, variables as to 'compliance' were coded. This approach shows that leximetrics can be extended beyond coding laws to establish whether market participants are complying with statutory requirements of non-financial reporting. In other words, we can use the leximetric approach to measure what is actually taking place

\footnotetext{
60 Lele and Siems (2007), p 19.

61 Pistor (2000).

62 Spamann (2010).

63 Cools (2006).

64 Siems (2010). It should be noted that more complicated methodologies are also being developed on a qualitative comparative basis. See LoPucki (2018).

65 Haslemann, Pistor and Vig (2010).

66 See Adams et al. (2017).

67 Siems (2008a).

68 Anderson et al. (2012).

69 Esser, MacNeil and Chalaczkiewicz (2018).
} 
in the market. We therefore use a leximetric approach to establish whether market participants are diverging from the default position contained in the Model Articles or not. Other empirical studies have reviewed whether market participants use default rules in corporate governance. ${ }^{70}$ Using leximetric techniques, we therefore establish whether market participants conform to the default regime across a number of variables, showing that these variables have met the aims of the UK government, or diverge from the default regime.

We establish whether market participants are using the Model Articles using public filing systems. A company's constitution, together with any changes to it, must be publicly filed. ${ }^{71}$ There have been recent reforms to the public register which increases its utility for empirical research. ${ }^{72}$ Whilst this register has always been publicly searchable, the search methods have been very cumbersome. A searcher was able to review data on 'microfiche', ${ }^{73}$ but this was particularly time consuming. This prevented the primary gathering of data, but more importantly, prevented the verification of any data collected which undermined the value of the quantitative research. This data was eventually uploaded online, and was accessible in exchange for payment for each document reviewed. On 22 June 2015 information became easier to access with the launch of a new website which offers a free 'beta' search of the Companies House data. ${ }^{74}$ The free data enables easier data gathering and verification, however, it does not contain all (especially historical) records of companies, and accordingly when faced with the two options the paid service is more reliable. Nonetheless, the beta service is especially useful for research, enabling free access to data for the primary data gatherer and any subsequent verification of that dataset by third parties. This is key to ensuring that the often stark results of leximetric analysis are, in fact, accurate. ${ }^{75}$ Between January 2018 and March 2018 there were 167,717 companies incorporated in the UK. ${ }^{76}$ If the rate of incorporation was constant then this implies over 6,000,000 companies have been incorporated since 1 October 2009. Reviewing all of these articles to establish whether they converge to or diverge from the Model Articles is impractical. Accordingly, we selected a sample of these companies.

\footnotetext{
70 Lin and Chang (2018).

71 Companies Act 2006, ss. 9 and 20.

72 See Hardman (2018).

73 Copies of all documents filed before 1 January 2003 were originally stored in this way, but are now mostly available for online access. See Howley and Bateman (2007), p 4.

74 See https://www.gov.uk/government/news/launch-of-the-new-companies-house-public-beta-service. Since the data used in this article was gathered, Companies House have replaced the 'beta' service with a fuller and more robust online search system. See https://find-and-update.company-information.service. gov.uk/.

75 See Spamann (2010).

76 See https://www.gov.uk/government/publications/incorporated-companies-in-the-uk-january-to-march 2018/incorporated-companies-in-the-uk-january-to-march-2018.
} 


\subsection{Sample Selection}

Of great concern was how to establish our sample. Given the number of companies, an holistic review of the entire database was not possible. We therefore needed to establish how to delimit the sample taken. One option was to take an entirely random sample, however, this would limit the data that arose from the sample: more recent companies have been in existence for a shorter period of time, and therefore any data received from them would be less helpful to establish whether companies changed their articles of association post-incorporation. Accordingly, we wanted the longest possible company life in order to track this. As our enquiry is limited to whether the UK government had met its aims in picking the Model Articles, we decided to pick the earliest set of companies so incorporated. Even within this, however, there were too large a number to code. We needed to narrow further. Our options were to take a randomised sample of the earliest companies, but this (once again) risked lacking an holistic overview of any particular sample group.

To resolve this issue, we narrowed our focus to companies incorporated in Scotland for a sample period: all those companies incorporated in Scotland within the first month of the new Model Articles regime, being October 2009. Narrowing to Scotland over the course of 1 month enabled us to review the entire sample and code the article of all companies incorporated within this group, without the need to select a section thereof. We use the term 'Sample' for this group. As the Companies Act 2006's provisions with regard to UK company incorporation were introduced on 1 October 2009, the Sample represents the oldest group of companies incorporated under this regime in Scotland. It therefore provides us with the longest possible period in which to evaluate what market participants have changed from the default regime for which specific companies. It also includes all companies registered in that jurisdiction within that time period, lowering the risk that any trends within that jurisdiction and incorporated at that time are missed. Upon registration, companies are each given an eight digit sequential number by UK Companies House which remains their unique identifying number. ${ }^{77}$ This is important as the names of companies can change, ${ }^{78}$ which may mean that tracking companies becomes difficult in the event of name 'swapping' between companies or frequent changes. All companies incorporated in Scotland have a unique six number digit code prefaced by 'SC' (in contradistinction to companies incorporated in England and Wales which have a unique eight number digit code). ${ }^{79}$ All UK companies also have a date of incorporation which is publicly available. Accordingly, to identify our sample groups, we begin with the lowest six number digit code prefaced by SC incorporated on the first date of the sample period, and include all sequentially numbered companies up to and including the highest six number digit code prefaced by SC incorporated on the last date of the sample period.

\footnotetext{
77 Companies Act 2006, s. 1066 .

78 Companies Act 2006, s. 77.

79 Companies Act 2006, s. 1066(2).
} 
Companies are incorporated in the UK by filling in the correct form and submitting it to Companies House. The company is formed on the date that Companies House processes the form. ${ }^{80}$ Since 1 October 2009, all UK companies have had to be incorporated using a form IN01, which means that the companies are incorporated under the 2006 Act regime. ${ }^{81}$ However, to ease transition from the Companies Act 1985 regime to the Companies Act 2006 regime, UK Companies House continued to process applications submitted under the Companies Act 1985 regime, provided that they were received by Companies House (albeit not yet processed) prior to 1 October 2009. ${ }^{82}$ Any such applicant is subject to the regime under the Companies Act 1985. Accordingly, we excluded any applications which fall under the Companies Act 1985 regime from our Sample. We are interested in focusing on UK private companies, and so we excluded any other form of company from our consideration, including entities incorporated as public limited companies, ${ }^{83}$ private companies limited by guarantee, ${ }^{84}$ or unlimited companies. ${ }^{85}$ Accordingly, there are some elements of the Sample which must be excluded from this group before undertaking the relevant leximetric analysis.

\subsection{Variable Selection and Coding}

Having identified our sample group, we next identified our variables. We have seen that presenters of a company must tick a box to state whether the Model Articles should apply in whole or in part. Whilst this can be the final position at the first stage of the analysis for those entities who do adopt the Model Articles in whole, it is not the final position for ostensibly bespoke articles: it is possible for a presenter to tick the 'entirely bespoke' articles box, but in fact append the Model Articles to the form. In such circumstances the Model Articles have, in fact, been adopted. Similarly, it is possible for a presenter to merely paraphrase the Model Articles, in which case the Model Articles have, in substance, been adopted. Accordingly, it is necessary to examine the content of the purported articles of association to establish not whether the Model Articles as a whole are adopted but whether specific articles adopted diverge from the Model Articles. We examined twelve potential variables within any articles of association. Our aim was purely to establish whether market participants are using the default regime across these twelve variables, avoiding Lele and Siems' critique of La Porta et al extrapolating from their variables more fundamental conclusions that are not shown by the variables used. We have further seen that functionality is a key element of leximetrics. This concept is generally applied to legal systems in comparative leximetrics when it comes to identifying the correct

\footnotetext{
${ }^{80}$ Companies House 2006, s. 14 and s. 16.

81 The Registrar's Rules 2009, vol. 2, Sch. 2 issued under Companies Act 2006, s. 117.

82 Companies Act 2006 (Commencement No. 8, Transitional Provisions and Savings) Order 2008 (2008/2860), Art. 5; Hardman (2020a).

83 Companies Act 2006, s. 4.

84 Companies Act 2006, s. 5.

85 Companies Act 2006, s. 3.
} 
variables ${ }^{86}$ but the principles can equally be applied to the concept of coding when testing deviation.

Initial leximetric studies used a 'binary' coding system (i.e., assigning laws with either 0 or 1). ${ }^{87}$ More recent leximetric studies have introduced a system of 'nonbinary' coding to encapsulate more of the complicated nature of the issues being discussed ${ }^{88}$ It has been stated that 'non-binary coding can lead to more meaningful results ${ }^{99}$ However, it can also lead to confusion as it increases complexity. If multiple numbers or fractions are used, then avoidable value judgements are introduced as to the differences between the variables-when averaging over larger datasets, using fractions implies set distances between the fractions. For example, it is tempting to measure full compliance with a default regime at ' 0 ', full deviation from the default regime as a ' 1 ', and a 'partial' deviation at a ' 0.5 '. However, this approach risks misleading results as not every partial deviation would be exactly halfway between full convergence and full deviation. A more qualitative figure allocated to the degree of deviation could allow the coder to ascribe a value to partial deviation in 0.1 increments which would reduce this problem. However, it would add an unnecessary level of subjectivity (and therefore make the results less verifiable) and was avoided.

Similarly, it was tempting to create added complexity by ascribing positive and negative numbers. For example, it is easy to imagine coding compliance with a default rule as ' 0 ', deviation in a 'shareholder friendly' way as ' +1 ' and deviation in a 'director friendly' way as ' -1 '. However, this results in the figures cancelling each other out on aggregation: a sample of 100 companies in which 50 diverged in a 'shareholder friendly' way, and 50 in a 'director friendly' way, would produce an average score of 0 , which implies pure convergence to the default rule instead of the full deviation that is actually seen. Accordingly, such an approach would complicate a simple overview of the Sample.

In order to avoid these complications, we use leximetrics merely to establish whether the market has moved away from the default regime in the UK. We therefore establish, for each of the variables identified, whether functionally the constitution of the company in question converges with the default regime or not. If it does converge, it receives a ' 0 ' and if it diverges it receives a ' 1 '. This enables us to establish which companies have functionally diverged from the default position for each of the variables. In other words, our study is deliberately limited to using the crudest form of leximetrics to establish quantitatively whether there is any deviation from the default regime across twelve variables only.

What, then, constitute our twelve variables and how are they coded?

\footnotetext{
${ }^{86}$ Lele and Siems (2007).

${ }^{87}$ La Porta et al. (1998); La Porta et al. (1997).

${ }^{88}$ For example, use of fractions in Siems (2008b).

89 Esser, MacNeil and Chalaczkiewicz (2018).
} 


\subsubsection{Weighted Voting}

Whilst the default position is that shares have equal number of votes, ${ }^{90}$ it has long been acknowledged that articles can provide for weighted voting. Whilst 'one vote one share' voting is generally considered optimal, ${ }^{91}$ there are many reasons to deviate from this model for private companies, from incentivising managers to providing strong institutional shareholders with more powerful blocking rights to reflect their importance. ${ }^{92}$ This can either be a constant variation in voting, ${ }^{93}$ or to provide additional rights to certain shareholders in certain circumstances. The former will be the case if, for example, every A share provides its holder with one vote per share and every B share provides its holder with two votes per share. ${ }^{94}$ The latter will be the case if, as in the classic case of Bushell v. Faith, shares usually attract one vote per share but on a vote to remove a director the shares held by that director attract three votes per share. ${ }^{95}$ For these purposes we will, of course, exclude the usual differences between the weight of voting on a show of hands ${ }^{96}$ and the weight of voting on a poll. ${ }^{97}$ Accordingly, our first variable is whether the articles in question adopt weighted voting or not. The Model Articles contain no weighted voting. Accordingly, articles without weighted voting are coded ' 0 ' and articles with weighted voting are coded ' 1 '.

\subsubsection{Entrenchment}

The Companies Act 2006 enabled any article of association to be "entrenched' ${ }^{98}$ An entrenched article is one that subverts the usual rule that the articles can be amended by way of special resolution. ${ }^{99}$ An entrenched article can be 'amended or repealed only if conditions are met, or procedures are complied with, that are more restrictive than those applicable in the case of a special resolution'. ${ }^{100}$ Accordingly, an article would be entrenched if it provides that it can only be amended with the agreement of $85 \%$ of the shareholders. Entrenched articles can either be included on formation ${ }^{101}$ or inserted by way of unanimous resolution. ${ }^{102}$ Our second variable is whether the articles in question have any articles entrenched or not. The Model Articles contain

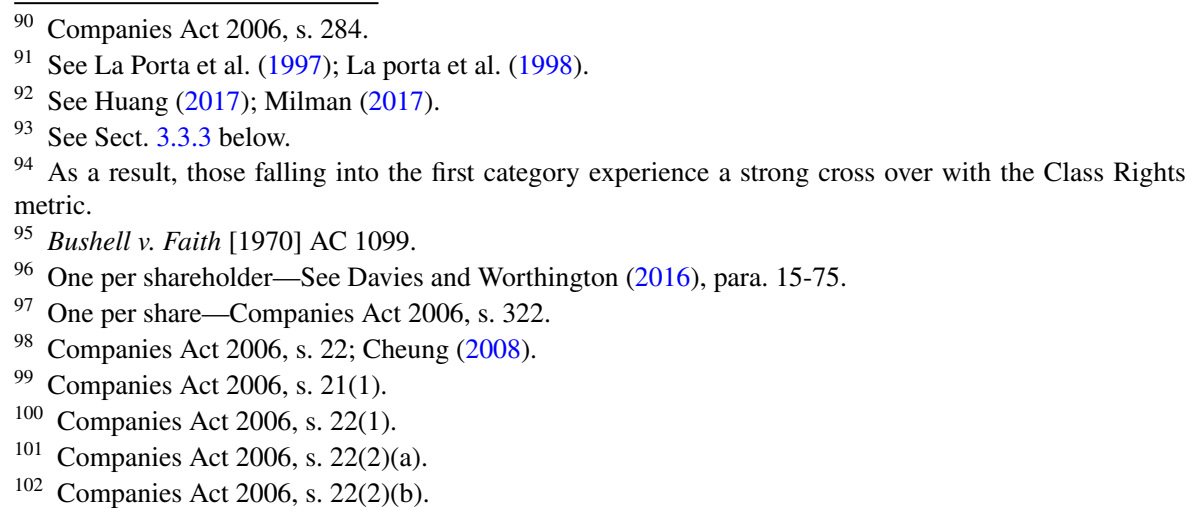


no entrenched provisions. Accordingly, articles without entrenched articles are coded ' 0 ' and articles with entrenched articles are coded ' 1 '.

\subsubsection{Class Rights}

The default position in the UK is that shares are all equal unless the articles of association provide otherwise. ${ }^{103}$ If they do provide otherwise, then the shares are divided into categories which reflect the various rights attached to shares, known as share classes. ${ }^{104}$ The presence of a class right provides additional protections to the holders of such shares: it protects the subject matter of the right from amendment by those not in that class. Thus if articles provide that a certain class of shares have a right to have a multiple of the votes able to be cast by other classes, such right is protected until the beneficiaries agree to its alteration, providing a protection for the minority who hold that class. ${ }^{105}$ Thus law holds that class rights can only be amended by the agreement of the majority of holders of that class, ${ }^{106}$ and in votes as to variations of class rights subvert the usual rules that every shareholder can vote in their own interest ${ }^{107}$ with a rule that, on votes as to variations of class rights, a shareholder must vote in the interests of that class. ${ }^{108}$ Our third variable is whether the articles of association contain class rights. Article 22 of the Model Articles provides:

Subject to the articles, but without prejudice to the rights attached to any existing share, the company may issue shares with such rights or restrictions as may be determined by ordinary resolution. ${ }^{109}$

Accordingly, coding of class rights involves two linked but technically separate concepts. Firstly, the Model Articles contain no embedded class rights. Secondly, their procedure for creating new shares with differing class rights is by way of the passing of an ordinary resolution by their shareholders. Accordingly, if the articles adopt both of these provisions then they are coded ' 0 '. If they contain either shares with embedded class rights, or provide for a different procedure to create class rights (for example, by way of resolution of the directors) then they are coded ' 1 '. It is tempting to separate these two elements, however both are integral to the class right regime operating with articles of association of any particular company and therefore are so heavily interlinked that it is necessary to conflate them. It should be noted that coding will only determine whether the articles of association contain embedded class rights, not whether different classes of shares have different rights (which

\footnotetext{
103 Birch v. Cropper (1889) 14 Appeal Cases 525.

104 See Morse et al. (2019), paras. 6.023-6.040.

105 See Polak (1986).

106 Unless the articles provide differently-Companies Act 2006, s. 630.

107 North-West Transportation Co v. Beatty (1887) 12 Appeal Cases 589.

108 Re Holders Investment Trust [1971] 1 WLR 583.

109 Model Articles, Art. 22.
} 
could be determined by reviewing the resolution constituting such class and never be included in the articles).

\subsubsection{Powers of Directors}

In the UK, the powers of directors are a matter of construction of the articles of association. ${ }^{110}$ Thus attempts of shareholders to undermine the rights that directors have according to the articles of association have been met with short shrift. ${ }^{11}$ The reliance on interpretation of articles of association to establish division of powers means that it is impossible to:

make general statements about the typical division of authority between shareholders and the board and management, because that is, in the main, open to be tailored to suit the individual company in question, ${ }^{112}$

but generally, articles of association provide wide powers to the board. ${ }^{113}$ Our fourth variable is whether the directors have unlimited power to undertake all activities that the company can make. It is important to note that this is a separate variable to whether or not the company can undertake any particular types of activity, ${ }^{114}$ this variable is instead concerned with who is authorised to undertake such activity on behalf of the company. Article 3 of the Model Articles provides:

Subject to the articles, the directors are responsible for the management of the company's business, for which purpose they may exercise all the powers of the company. ${ }^{115}$

The main limitation on this is Article 4, which enables the shareholders to pass a special resolution to 'direct the directors to take, or refrain from taking, specified action'. ${ }^{116}$ This power is limited to future directions and so cannot have retrospective effect. ${ }^{117}$ The rationale for such a wide power to the directors is that 'the Government believes that it is worth setting out in the articles the breadth of directors' general authority as agents of the company'. ${ }^{118}$

Once more, this provides a series of linked default rules: that directors have unlimited power where shareholders can, by special resolution, direct the directors to act in a certain way, and that any such direction cannot have retrospective effect. If the articles match this series of linked rules then they are coded ' 0 '. Any variance from this is coded ' 1 ', including:

\footnotetext{
$\overline{110}$ Davies and Worthington (2016), para. 14-3.

111 Shaw \& Sons (Salford) Ltd v. Shaw) [1935] 2 KB 113 at 134.

112 Davies and Worthington (2016), para. 14-5.

113 Cheffins (2008), p 603.

114 For which please see Sect. 3.3.12.

115 Model Articles, Art. 3.

116 Model Articles, Art. 4(1).

117 Model Articles, Art. 4(2).

118 Department of Trade and Industry (2007), para. 3.46.
} 
a. any embedded restriction on the powers of directors;

b. any ability to direct shareholders by a lesser or greater majority than special resolution; or

c. any ability for instructions to have retrospective effect.

Once more, it is tempting to split out these into separate variables, however as they work together to produce a single regime for the powers of directors, our concern is purely whether this regime is followed in full or not.

\subsubsection{Appointment of Directors}

When it comes to the appointment of directors in the UK, the Companies Act 2006 'says little about the means of appointing the directors, leaving this to the articles of association'. ${ }^{119}$ In particular, 'shareholders could be wholly written out of the appointment process'. ${ }^{120}$ Our fifth variable is therefore the methods for appointing directors. Model Article 17 provides:

Any person who is willing to act as a director, and is permitted by law to do so, may be appointed to be a director-

a. by ordinary resolution, or

b. by a decision of the directors. ${ }^{121}$

As with previous variables, the default rule could technically be broken into whether there is an ability for shareholders to appoint directors and an ability for directors to appoint directors. However, splitting the variable risks making the result less clear: if the variable was split into two, then an article which replaced the word 'or' with the word 'and' above would be difficult to code. Again, we test the default regime for appointment of directors as a whole. The caveat at the start of this variable is also important: any equivalent caveats about directors requiring to be willing, or being permitted by law to be directors (including related to their capacity (due to minority ${ }^{122}$ or otherwise)) are disregarded as variances on the grounds of the functionality principle. Ability for shareholders to appoint directors by ordinary resolution or a decision of the directors appointing a director shall be coded with ' 0 ', any variance from this (be it a requirement for a special resolution rather than ordinary, a limitation on either organ appointing directors or otherwise) are coded with ' 1 '.

\footnotetext{
119 Davies and Worthington (2016), para. 14-23.

120 Davies and Worthington (2016), para. 14-48.

121 Model Articles, Art. 17.

122 E.g. Companies Act 2006, s. 157.
} 


\subsubsection{Dismissal of Directors}

Shareholders have a statutory right to remove a director of a UK company by ordinary resolution at any time. ${ }^{123}$ This right is subject to special notice provisions ${ }^{124}$ and cannot be achieved by written resolution. ${ }^{125}$ In addition, 'the articles may provide additional grounds for the removal of directors, the most common being a request from fellow directors. ${ }^{126}$ Davies and Worthington indicate ${ }^{127}$ that this may not be strictly required, on the grounds that the court has previously held that life directors can ask ordinary directors to resign, ${ }^{128}$ and have held that a majority of directors have a right to ask a director to resign. ${ }^{129}$ However, in the absence of a clear provision in the articles the precise ambit of this right is unclear: will the courts include any requirement as to reasonableness on the other directors? Our sixth variable is, therefore, the circumstances in which a director can be made to resign by either directors or shareholders (and, in the latter case only, in addition to the statutory provisions).

Model Article 18 provides:

A person ceases to be a director as soon as-

a. that person ceases to be a director by virtue of any provision of the Companies Act 2006 or is prohibited from being a director by law;

b. a bankruptcy order is made against that person;

c. a composition is made with that person's creditors generally in satisfaction of that person's debts;

d. a registered medical practitioner who is treating that person gives a written opinion to the company stating that that person has become physically or mentally incapable of acting as a director and may remain so for more than 3 months; or

f. notification is received by the company from the director that the director is resigning from office, and such resignation has taken effect in accordance with its terms. ${ }^{130}$

These provisions are all either automatic or in the control of the director whose termination is in question. Deferring to the functionality principle, the key coding issue is that a director ceases his or her termination by his or her own choice or automatically due to a prescribed event. There is no ability in the Model Articles for the other directors to procure that removal nor for shareholders to do so in addition to

\footnotetext{
123 Companies Act 2006, s. 168.

124 Companies Act 2006, s. 168(2).

125 Companies Act 2006, s. 288(2).

126 Davies and Worthington (2016), para. 14-49.

127 Davies and Worthington (2016), para. 14-49.

128 Bersel Manufacturing Co Ltd v. Berry [1968] 2 All ER 552 HL.

129 Lee v. Chou Wen Hsien [1984] 1 WLR 1201.

130 Model Articles, Art. 18. Limb (e) was deleted by the Mental Health (Discrimination) Act 2013, s. 3.
} 
the statutory right of shareholders to do so. Interestingly, when proposing the Model Articles, the UK government stated that it 'has decided to include the notion of failure to attend meetings in the more general provision under which appointment terminates when all the other directors decide that a director should be removed from office'. ${ }^{131}$ However, no such provision was ever actually included in the Model Articles. Accordingly, this variable is coded ' 0 ' where termination events are either at the option of the outgoing director or automatic, and ' 1 ' where other parties (be it shareholders, other directors or third parties) have the ability to require a director to resign.

\subsubsection{Restrictions on Share Transfers}

Unless shares in UK companies are held in uncertificated form in CREST, ${ }^{132}$ in order to transfer them a form which can be stamped must be duly signed and then stamped. ${ }^{133}$ Legal title, however, only passes when the transferee is entered into the register of members as holder of the shares, which has to be undertaken by the company. The result is a regime which provides: 'a closed company [with] the opportunity to control the process of transfer of shares to new holders'. ${ }^{134}$ The power to refuse to transfer shares only arises if it is contained in the articles of association, ${ }^{135}$ must be applied in the best interests of the company ${ }^{136}$ and, following implementation of the Companies Act 2006, requires directors to provide reasons for any refusal to transfer. ${ }^{137}$ Nonetheless, this only amounts to providing a rationale rather than any further substantive limitation on such power. Our seventh variable will therefore be the extent to which directors are able to refuse or delay the transfer of shares. Model Article 26 provides:

The directors may refuse to register the transfer of a share. ${ }^{138}$

Accordingly, the Model Articles provide directors the utmost discretion, without the boundaries of the law, to refuse to transfer shares. Absolute discretion by directors to refuse to transfer shares will therefore be coded ' 0 '. Any inhibition on their discretion to refuse to transfer, including by way of a mandatory 'permitted transfer' mechanism under which the directors are obliged to accept certain transfers, or by way of a 'prohibited transfer' mechanism whereby there are certain categories of transfers which the directors are obliged to reject, is coded ' 1 '.

\footnotetext{
131 Department of Trade and Industry (2007), para. 3.101.

132 Uncertificated Securities Regulations 2001 (SI 2001/3755) and Morse et al. (2019), para. 6.502.

133 'Stamping' involves paying a tax of $0.5 \%$ the value of the transferred shares to the UK tax authority, HMRC, at which time the relevant form is physically stamped to indicate such tax has been paid. See Stock Transfer Act 1963, s. 770(1).

134 See Davies and Worthington (2016), para. 27-5.

135 Morgan v. Morgan Insurance Brokers Ltd [1993] BCC 145.

136 Re Smith \& Fawcett Ltd [1942] Ch 304.

137 Companies Act 2006, s. 771(2).

138 Model Articles, Art. 26.
} 


\subsubsection{Ability of Directors to Authorise a Conflict of Interest}

It has long been accepted in the UK that directors owe fiduciary duties to the company and are under an obligation to avoid having a conflict of interest with the company. ${ }^{139}$ This currently has a statutory form. ${ }^{140}$ The statutory form, however, allows a conflict of interest of one director to be authorised by another director "where the company is a private company and nothing in the company's constitution invalidates such authorisation, by the matter being proposed to and authorised by the directors. ${ }^{141}$ Our eighth variable is therefore whether anything in the company's constitution prevents the directors from authorising a conflict of interest by a director. This metric is, of course, to be differentiated from a subsequent ability for a conflicted director to count towards the quorum for a board meeting: articles of association may or may not provide for such ability, but that is a different question than whether, and only arises if, the directors are able to authorise the conflict in the first place.

The Model Articles do not prevent directors from authorising a conflict of interests of directors. Whilst they do provide that generally conflicted directors are not able to count towards the quorum, as noted above this is a different consideration to whether the directors are prevented by the articles from utilising their otherwise statutory right to approve conflicts of interest by a director. The rationale the UK government has provided for this approach is that, as Parliament has decided a default rule in favour of allowing conflicts, it would be incorrect for the Model Articles to instead provide a default rule which provided the opposite. ${ }^{142}$ Accordingly if the articles are silent or expressly allow such then they are coded ' 0 ' and if the articles prevent directors from authorising conflicts then they are coded ' 1 '.

\subsubsection{Authorised Share Capital}

Prior to the implementation of the Companies Act 2006, there was a requirement for a UK company to state in its memorandum of association its maximum authorised share capital: the maximum amount of share capital that could be issued. ${ }^{143}$ The company would only be able to have share capital issued which exceeded this amount with prior authorisation from shareholders. ${ }^{144}$ This is, of course, different from the amount of share capital of the company in issue from time to time. The result was that:

The company's authorised capital might have been 10 million shares of $£ 1$ each, but if only two of those shares had been issued, say at par, then its

\footnotetext{
139 See Bray v. Ford [1896] AC 44, discussed in Davies and Worthington (2016), para. 16-52.

140 Companies Act 2006, s. 175(1).

141 Companies Act 2006, s. 175(4)(b).

142 Department of Trade and Industry (2007), para. 3.76.

143 See Companies Act 1985, s. 2(5)(a).

144 Companies Act 1985, s. 121.
} 
legal capital was $£ 2$. If anything, authorised capital served to confuse the potential investor. ${ }^{145}$

The Companies Act 2006 contains no provision requiring an authorised share capital, and therefore UK companies do not have to include one. In line with the general analysis adopted, however, they could do so if they wish. Authorised share capital has the potential to regulate relations between directors and shareholders: it can be considered a cap on any general authority to allot shares provided to the directors from time to time. Our ninth variable is therefore whether the company's articles of association contain an authorised share capital. It should be noted that this is different from any cap that the directors have in their authority to issue: authorised share capital is a more fundamental question of the amount of shares that a company can have in issue at any time without shareholder consent rather than a limit on how many shares the directors are able to issue within a specific period.

The Model Articles do not include an authorised share capital. Accordingly, articles which are silent as to authorised share capital or expressly provide that there is no limitation to the maximum amount of share capital which can be in issue are coded ' 0 ', and any limitation on the authorised share capital of a company are coded ' 1 '.

\subsubsection{Ability of Directors to Change the Name of the Company}

Historically, the only way to voluntarily change a UK company's name was by way of a shareholder resolution. ${ }^{146}$ The Companies Act 2006 retained this right ${ }^{147}$ and in addition brought in a new ability for a company to voluntarily change its name 'by other means provided for by the company's articles'. ${ }^{148}$ This could include allowing directors to change the name of the company. Our tenth variable is therefore whether the articles of association contain a right for directors to change the name of the company.

The Model Articles do not provide for the directors to be able to change the name of the company. Accordingly if articles are silent or a statement is included expressly preventing the directors from changing the name of the company then they are coded ' 0 ' and if directors are expressly able to amend the name of the company then they are coded ' 1 '.

\subsubsection{Ability for Directors to Appoint Alternate Directors}

It has been stated that in the UK ' $[\mathrm{t}]$ he office of director is a personal responsibility and can only be discharged by the person holding that office, except to the extent that

\footnotetext{
145 Davies and Worthington (2016), para. 11-12.

146 See Companies Act 1985, s. 28.

147 Companies Act 2006, s. 77(1)(a).

148 Companies Act 2006, s. 77(1)(b).
} 
the company's articles make explicit provision. Many companies' articles provide that, in certain circumstances, directors may appoint an alternate to act in their absence. ${ }^{149}$

Ability to provide for alternate directors must be included in the company's articles of association to be allowed. There is no automatic imputation of knowledge between the appointer and the alternate, ${ }^{150}$ and so an alternate's ability to count towards a quorum will not be affected by a conflict of their appointer, ${ }^{151}$ but the alternate's own conflicts will be relevant for the analysis. ${ }^{152}$ Our eleventh variable therefore is whether the directors are able to appoint alternates or not.

The Model Articles do not provide for the appointment of alternate directors. Interestingly, Table A did provide for the appointment of alternate directors under the pre-2006 act regime. ${ }^{153}$ The rationale for not including the ability to appoint alternates in the private articles was 'the Government considers it unlikely that the directors of most private companies will want to appoint alternates'. ${ }^{154}$ Articles are therefore coded ' 0 ' if they do not allow for the appointment of alternate directors and are coded ' 1 ' if they do allow for the appointment of alternate directors, whatever restrictions are placed on such appointment.

\subsubsection{Restriction on the Company's Objects}

Historically, UK companies had to have a statement of their objects, i.e. the action that the company could enter into and for what ends, in their memorandum of incorporation. ${ }^{155}$ Actions not within the company's objects used to be outside the competence of the company. ${ }^{156}$ This led to considerable debate as to whether a particular provision was an object (i.e. something that the company should strive towards) or a power (i.e. the steps that were taken to achieve this). ${ }^{157}$ This began to change with the Companies Act 1989, which stated that:

the validity of an act done by a company shall not be called into question on the ground of lack of capacity by reason of anything in the company's memorandum. ${ }^{158}$

This has been retained in the Companies Act 2006. ${ }^{159}$ Similarly, the Companies Act 2006 removed any requirement that a company state its objects. ${ }^{160}$ It did, however, leave the option open to a company: a company incorporated since 1 October

\footnotetext{
149 Morse et al. (2019), para. 8.211.

150 Re Associated Tool Industries Ltd (1963) 5 FLR 55.

151 Anaray Pty Ltd v. Sydney Futures Exchange Ltd (1988) 6 ACLC 271.

152 Australian Securities \& Investments Commission v. Doyle \& another [2001] WASC 187.

153 See Companies (Table A to F) Regulations 1985, Arts. 65-69.

154 Department of Trade and Industry (2007), para. 3.107.

155 See Companies Act 1985, s. 2(1)(c).

156 Nyombi (2014).

157 Omar (2004).

158 Companies Act 1989, s. 108.

159 Companies Act 2006, s. 39.

160 Companies Act 2006, s. 31(1).
} 
2009 is presumed to have unlimited objects if that company choses to include a restriction on objects in its articles of association. ${ }^{161}$ The shareholders of a company may wish to limit the objects of the company if the company is only meant to exist for, or undertake, a specific purpose. For example, if a company is only established to hold a specific property for investment purposes but only one shareholder is involved in management at all, then the corporate participants may wish to include a limitation of the objects of the company to doing so. Third parties are protected by a statutory provision:

in favour of a person dealing with a company in good faith, the power of the directors to bind the company, or authorise others to do so, is deemed to be free of any limitation under the company's constitution. ${ }^{162}$

Even with this provision, shareholders are able to apply to the court to restrain the directors from acting in a manner which contradicts the articles of association of the company ${ }^{163}$ and directors can still be in breach of their duties if they breach the company's constitution. ${ }^{164}$ Accordingly, any objects clause of the company remains relevant. The twelfth and final variable is, therefore, whether the articles of association have a restriction on the objects of the company or not.

The Model Articles do not restrict the objects of the company. Accordingly, articles which do not restrict the objects of the company are coded ' 0 ' and articles which do restrict the objects of the company are coded ' 1 '.

\subsubsection{Summary}

A summary of the variables we have coded and the coding for each such variable is therefore provided in Table 1.

As noted above, a UK company's constitution can be amended by the shareholders. Therefore, we need to code these variables for each constitution not only on incorporation of the company, but also for any amendment that may be subsequently made after incorporation.

\section{Results}

\subsection{Results on Incorporation}

\subsubsection{Sample Overview}

The Sample consists of 1417 companies. Details of the companies involved in the Sample, together with the coding of variables in line with the foregoing are included

\footnotetext{
161 Companies Act 2006, s. 31(1).

162 Companies Act 2006, s. 40(1).

163 Companies Act 2006, s. 40(4).

164 Companies Act 2006, ss. 40(5) and 171(a).
} 


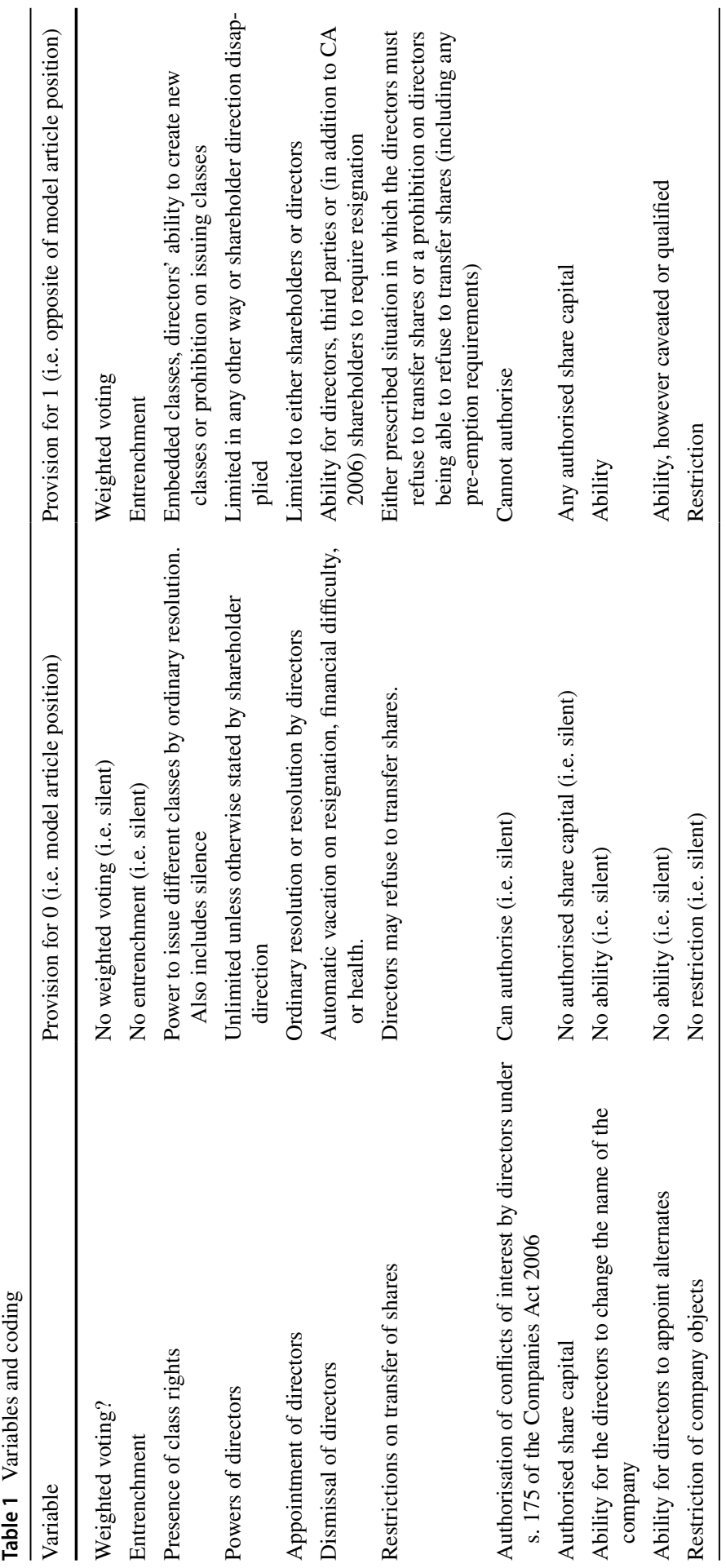


in the dataset. ${ }^{165}$ The dataset contains company numbers, names, the details of types of articles included, and coding of the twelve variables. The documents on which the dataset is based were downloaded between January and March 2018, and reflect the constitutions of the Sample from the incorporation of each company in the Sample to 31 December 2017. The dataset is publicly available to enable readers to verify the outcomes outlined in this article with their own analysis to replicate the study. When we apply our exclusions from the Sample:

a. 8 were incorporated using forms from the Companies Act 1985 regime that must have been received from Companies House prior to 1 October 2009 but have only been processed after. Accordingly, they are incorporated on the 1985 Act's terms and so are excluded;

b. 24 are not private limited companies and so are excluded (20 are companies limited by guarantee, 3 are public limited companies and 1 is an unlimited company); and

c. 291 company numbers were not listed as corresponding to UK companies at Companies House beta. The formal paid site, Companies House Direct, confirms that the majority of these companies were incorporated in October 2009 but had all been dissolved by June 2012. These companies are listed as having company name 'None' in the dataset. No further information in respect of these companies was publicly available for free when the documents in respect of the Sample were downloaded and they therefore are excluded on the grounds that no data in respect of them is publicly available for free.

Accordingly, the initial 1417 becomes 1094 companies in the Sample.

We have noted that, on incorporation, corporate participants have the ability to tick a box to apply the Model Articles wholesale, partially, or to adopt entirely bespoke articles. A summary of the boxed ticked across the Sample is contained in Table 2

This appears to demonstrate that the Sample indicates that the Model Articles are not efficient default rules. However, this demonstrates the risks of overinclusion in the leximetrics of divergence: simply because nearly $72 \%$ of incorporated companies purported not to adopt the Model Articles does not mean that they in fact did so, they may have included the same terms as the Model Articles (either identically or functionally). Even if this is not the case for the Model Articles in their entirety, it may be that not all variables are diverged from. Accordingly, in line with the general approach taken on coding, we examined the 844 companies from the Sample who did not wholly adopt the Model Articles to establish which variables are being diverged from.

165 Hardman (2020b). 
Table 2 Whether the sample indicated they adopted the model articles wholesale, in part, or excluded them

\begin{tabular}{lll}
\hline Box ticked in IN01 & Number & Percentage (\%) \\
\hline Option 1 (model articles adopted wholesale) & 250 & 22.85 \\
Option 2 (partially adopted model articles) & 61 & 5.58 \\
Option 3 (adopted entirely bespoke articles) & 783 & 71.57 \\
Total & 1094 & 100 \\
\hline
\end{tabular}

\subsubsection{Article Metrics}

The coding of variables for the 1094 companies constituting the Sample on incorporation are outlined in the dataset and the results are as summarised in Table 3.

The ability to appoint alternate directors is the only variable which the majority of companies diverged from on incorporation. Interestingly, Table A did allow for appointment of alternates.

\subsection{Results on Amendment}

\subsubsection{General}

Of our Sample, only $63(5.76 \%)$ ever changed their articles. This is a key insight as it implies that a UK private company's constitution is not frequently amended.

Table 3 Results of coding variables for the sample on incorporation

\begin{tabular}{lll}
\hline Variable & $\begin{array}{l}\text { Number of divergent } \\
\text { (i.e. coded '1') }\end{array}$ & $\begin{array}{l}\text { Percent of } \\
\text { divergent arti- } \\
\text { cles (\%) }\end{array}$ \\
\hline Weighted voting & 9 & 0.8 \\
Entrenchment & $1^{\mathrm{a}}$ & $<0.1$ \\
Presence of class rights & 22 & 2 \\
Powers of directors & 12 & 1 \\
Appointment of directors & 38 & 3.47 \\
Dismissal of directors & 38 & 3.47 \\
Restrictions on transfer of shares & 238 & 21.76 \\
Authorisation of conflicts of interest by directors under s. 175 & 2 & $<0.2$ \\
$\quad$ of the Companies Act 2006 & 7 & 0.6 \\
Authorised share capital & 176 & 16.1 \\
Ability for the directors to change the name of the company & 628 & 57.4 \\
Ability for directors to appoint alternates & 5 & 0.4 \\
Restriction of company objects &
\end{tabular}

${ }^{a}$ Interestingly, this set of articles did not actually entrench any articles, merely ticked a box in the incorporation form which stated that an article was entrenched, without actually providing for an entrenched article. 
Of these, 47 only made one change, 14 made a further change to their articles and 2 companies changed their articles twice more. $25.4 \%$ of companies who changed their articles went on to change them again. This is considerably higher than the c5\% of companies who initially changed their articles. This combination results in there being 81 changes to articles of association across the Sample, and shows that a company is more likely to change their articles if they have already changed them previously. Articles can be amended by way of a simple amendment to them or by wholesale replacing them with new articles. Of our 81 changes, 4 were amendments and a full 77 were restatements with new articles. The Sample group therefore indicates that articles are more likely to be restated in full than merely amended.

Of the amendments, one introduced a new share class with weighted voting, two changed the transfer mechanics and one introduced an article to deal with beneficial ownership.

\subsubsection{Results by Variable}

Of the restated articles, the coding across the 77 is as outlined in the dataset and the results are as summarised in Table 4.

Other than an ability for the directors to change the name of the company and the false positive for entrenchment on incorporation, these percentage variations are higher than on incorporation. Whilst alternate directors also remain above $50 \%$, over $50 \%$ of restated articles include change to the default on class rights (frequently embedded classes), removal of directors and share transfers.

This therefore shows that subsequent amendment is likely to be further divergent from the default rules than on incorporation. This matches the UK government's aims for the Model Articles to meet the requirements of most companies, with those who care sufficiently able to change their own constitutions. This would also fit neatly with the Model Articles being designed for smaller companies as part of the 'think small first' regime.

It is generally possible to code the amendment by any form of evident rationale for the changes. This is taken from comparing the coding for each relevant company's new articles to the coding for their previous articles and examining the key changes, and is set out in Table 5.

Of our 81 sub-sample of the Sample which amended their articles, we can therefore remove the 23 that made no changes, to reduce the sample group for these purposes to 58. Of that 58, 45 (consisting of the first three rows in Table 5 above, and $77.59 \%$ of the revised Sample amendment group) appear to relate to a reaction to capital events in the company: introduction of a new share class either implies that a new share class has been, or is about to be, issued, and similarly the introduction of an ability for shareholders to override the activities of the directors implies that the company in question is joining a corporate group.

The low percentage of companies amending their articles, together with the high level of those amendments seeming to be linked to capital events, would seem to support the analysis that, if the Model Articles are updated to allow for alternate 


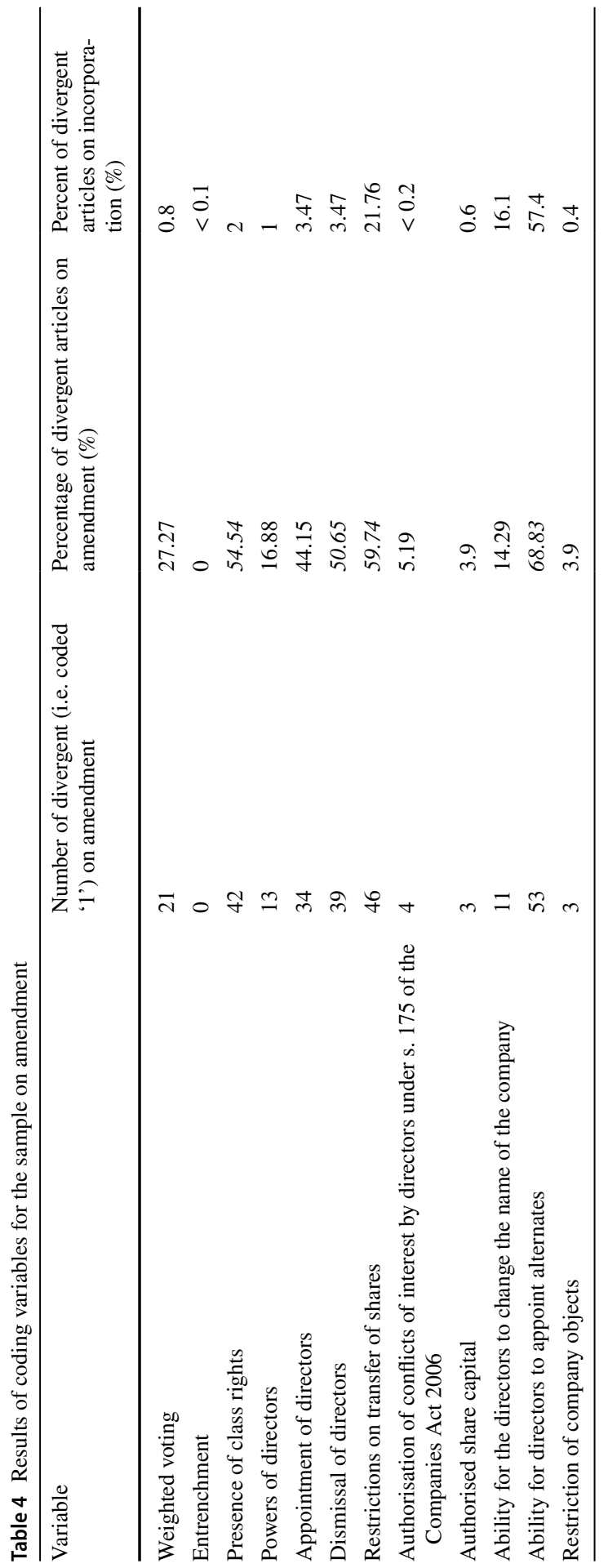




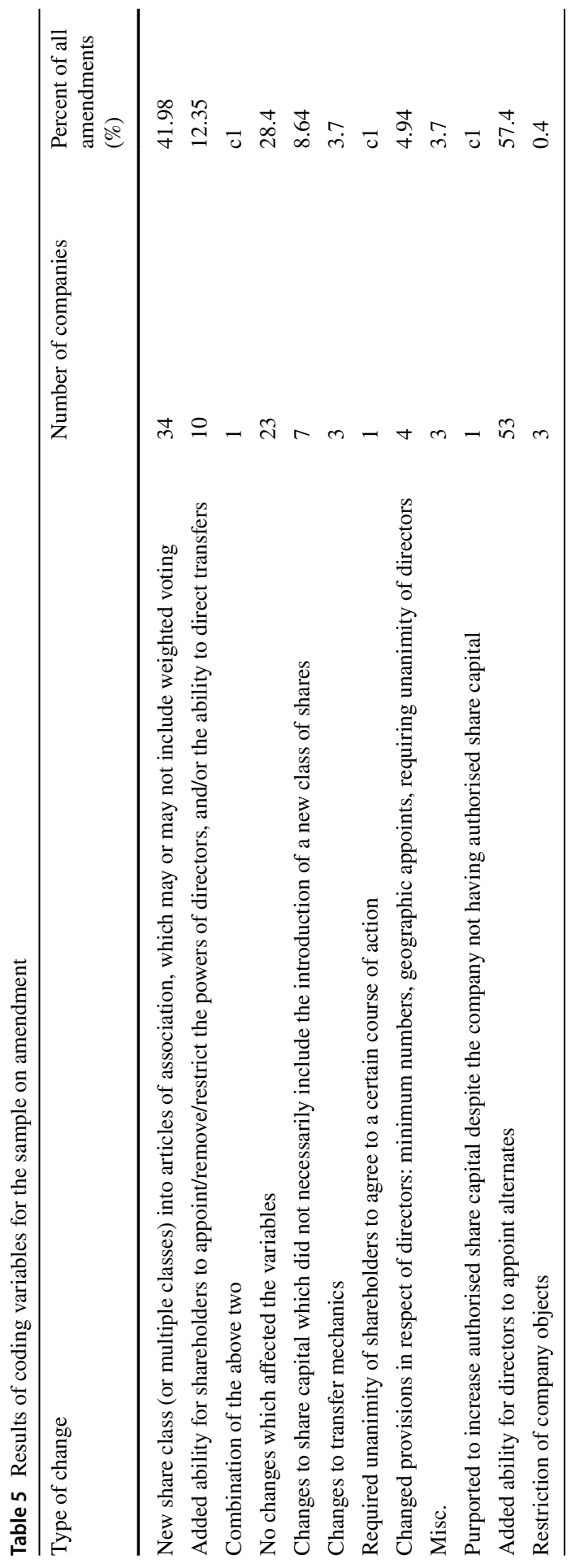


Table 6 Formation agent

\begin{tabular}{|c|c|c|c|}
\hline Presenter detail & $\begin{array}{l}\text { Number of } \\
\text { presenters in } \\
\text { category }\end{array}$ & $\begin{array}{l}\text { Number of } \\
\text { companies }\end{array}$ & Percentage $(\%)$ \\
\hline Did not state that the company had a 'presenter' & N/A & 30 & 2.74 \\
\hline Presented only one company in the Sample & 39 & 39 & 3.56 \\
\hline $\begin{array}{l}\text { Presented more than one company with no vari- } \\
\text { ance as between the companies that they have } \\
\text { presented: if one of their companies adopted } \\
\text { Model Articles then all did, and similarly if } \\
\text { all provided, for example, an ability for the } \\
\text { directors to change the name of the company } \\
\text { then all did }\end{array}$ & 43 & 508 & 46.43 \\
\hline $\begin{array}{l}\text { Presented more than one company with vari- } \\
\text { ance as between the companies that they have } \\
\text { presented }\end{array}$ & 9 & 517 & 47.26 \\
\hline Total & 91 & 1094 & $\begin{array}{l}99.99 \text { (rounding } \\
\text { error for final } \\
0.01 \% \text { ) }\end{array}$ \\
\hline
\end{tabular}

${ }^{a}$ Incredibly, the same typing mistake (a repetition of a clause heading instead of a new name being used) appears in all companies presented by 7 presenters, representing 76 companies (i.e. $6.9 \%$ of the total), and all 46 companies presented by one presenter (@UKPLC) contained the same footnote which appears to be accidentally left over from the tailoring process

directors, then across the twelve variables they meet the UK government's aim of drafting the Model Articles on a majoritarian default basis.

\subsection{Results on Presenters}

Of particular note is the relevance of formation agents within the Sample. Companies in the Sample were presented by 91 different formation agents. Presenters and coding are outlined in the dataset. Formation metrics or presenters are set out in Table 6.

This seems to present mixed evidence for Davies and Worthington's suggestion that the presenter of a company may dictate its articles of association. Over $97 \%$ of the Sample used a presenter, implying that their use is prevalent. Of that number, 39 presenters only presented one company and it is therefore impossible to tell whether their articles were standard or bespoke. Once the 'no presenters' and the 'only one presenters' are removed from the sample, that leaves 1,025 companies in the Sample. Of those, $49.56 \%$ showed no variance within the coding in respect of companies they presented and $50.44 \%$ showed a variance between them, implying that presenter choice was important but not the sole consideration in the choice of articles. Interestingly, however, the former is represented by 43 presenters and the latter by 9 , which seems to imply that there are more presenters (by number) who consistently apply the same articles, and yet the presenters 
who offer bespoke articles (or those who offer alternative versions of articles) are more commonly utilised within the market place.

Of the 9 presenters for whom there was a change as between the companies that they presented:

a. Jordans presented the most companies of the Sample (423 companies, or $38.67 \%$ of the sample total). Of these 423 companies, 402 (or 95.04\%) were coded consistently. Of those that diverged from this usual coding pattern, 16 varied from the usual Jordan's approach to share transfers, 4 gave directors the ability to change the name and 1 included an extra element on director removal. Overall, even though Jordans did evidence some divergence, the vast majority of companies presented by them were consistent-and the main variance they have from the model articles is that they provide for alternate directors to be included in every single of their presented companies;

b. Cosun Formations presented 12 companies. 9 contained embedded share classes with specific transfer obligations (in particular, the same wording as to employee shares) and 3 did not. Other than this, they are in alignment;

c. Formations Direct presented 25 companies. 24 are in full alignment with each other and the 25th has articles in the same alignment, but ticked box 'Option 1 Private' instead of Option 3. It appears as if this was by accident as the form IN01 also attached this presenter's usual articles;

d. First Corporate Law Services presented 29 companies, in which 3 have embedded multiple classes and 26 do not. 28 have variations from the model articles as to transfer, and 1 does not;

e. LtdOnline presented 14 companies, 8 of which are 'Option 1' companies, and the remaining 6 are split between 3 different forms of articles;

f. 7side Limited presented 5 companies in 2 different forms;

g. Burness LLP presented 3 companies in 2 different forms;

h. McGrigors LLP presented 3 companies in 2 different forms; and

i. Waterlow presented 3 companies which were all identical other than one company not including a limitation on the company's objects.

In other words, even within the category of those presenters who presented different forms, the level of divergence from their standard forms is low. It seems as if Davies and Worthington's suggestion that the presenters have their own forms is empirically verified within the Sample - and that choice of presenter may be a primary determinant of the constitution of a UK private company.

\section{Implications and Further Study}

\subsection{Implications}

The outcome of the empirical study has three key implications. Firstly, of the variables selected, the vast majority of companies in the Sample followed the variables 
selected as set out in the Model Articles. Only the default position on alternate directors is not followed by a majority of the Sample on incorporation. Alternate directors were not provided for in the Model Articles for private companies as 'the Government considers it unlikely that the directors of most private companies will want to appoint alternates'. ${ }^{166}$ This empirical study casts doubt upon whether that conclusion was correct, and provides evidence that alternates are sought after in the market by a majority of private companies.

Secondly, the level of subsequent amendment of articles within the Sample is low. This implies that companies do not frequently amend their articles of association. Such amendments as there were appeared to be linked to specific capital events in the lifecycle of the company. Accordingly, the UK government seem to have been correct when adopting the idea that they should pick the Model Articles based on smaller companies, and more complex companies can adjust their own constitution, as necessary.

Thirdly, presenters of companies are frequently used within the Sample, and the presenter picked has a strong influence on the form of the articles of association that are picked. Of course, we cannot extrapolate causation from correlation: it could be that market participants pick the presenter based on the form of constitution that they deploy, or that each client of the presenter happened to have uniform needs. However, it is sufficient to note that presenters play a key role in establishing the corporate contract for private companies. Their use is currently suggested by the UK government, but it may be necessary for further scrutiny to be paid to the role of presenters in establishing the constitution of the UK private company. ${ }^{167}$ This is especially the case as the majority of companies do not change their articles of association post-incorporation, meaning that choices made by the presenters are likely to have long lasting implications. In addition, the reliance of UK company law on the articles of association places the constitution as a key element of company law more broadly. The impact of unregulated presenters on company law has been assumed by commentators. This study empirically indicates their importance: it may be time to pay more attention to them.

\subsection{Critique}

The foregoing implications, however, need to be considered with caution. There are a number of critiques which can be made of the study outlined in this article. We can provide responses to all such critiques, but it cannot be doubted that they do curtail how extrapolatable the outcomes of this study can be said to be.

Firstly, there could be issues of sample selection. Of course, the bigger the sample the more that can be drawn from it. We limited the Sample in two ways: by jurisdiction and by time. The former of these means that the outcome may be limited to

\footnotetext{
166 Department of Trade and Industry (2007), para. 3.107.

167 The UK Government is currently proposing to verify the identity of those establishing companies, but this article verifies how important presenters are in the constitution of the company. See Department for Business, Energy \& Industrial Strategy (2020), paras. 123-129.
} 
an insight into Scottish companies, without any wider application to the UK governance framework. Even if this is the case, however, this would be noteworthy. Whilst there are some differences in law between England and Scotland, company law generally is seen as being of uniform application between the two jurisdictions. ${ }^{168}$ Accordingly, even if the results are limited in application to Scotland, and these are entirely different in England, this would be an important development in understanding any differences in law and practice between England and Scotland.

The latter of the Sample limitations, limiting the Sample to the oldest companies under the Model Articles regime, can also be criticised. It provided the longest life of companies, and therefore gave the best insights into the likelihood of amendment of articles over the life of companies under the new regime. However, it does not show current market practice. We have also seen that our main divergence from the Model Articles, allowing for alternate directors, was included in the previous regime. There is therefore a chance that presenters were merely path dependent, rather than market participants particularly desiring the ability to have alternate directors. Whether it applies to legal reform ${ }^{169}$ or the activities of market participants, ${ }^{170}$ rules and structures which applied previously may continue to be applied even after their apparent removal. Margolis and Liebowitz provide 3 types of path dependence:

1. First degree path dependence arises where a decision has an element of 'persistence or durability, ${ }^{171}$ in other words where a current decision is affected by previous decisions.

2. Second degree path dependence arises where imperfect knowledge of the future means that one makes a decision which subsequently turns out to have been the incorrect decision: they use the example of a decision to build a house at a site which has a sewerage plant built next to it 5 years later. At the time, this could not have been known, but a previous decision proves to have not been the correct decision and now it is too late for the economic actor to amend it.

3. Third degree path dependence arises where the economic actor has full information but choses to make an incorrect decision: if they know that a sewerage plant will be built next to their plot but decide to build there anyway because their friends all live nearby.

For our purposes, the continued use of alternate directors could arise from any of the above three but seems most likely to be first degree or third degree: it may be that a presenter simply has no reason to delete alternate director provisions from pro forma articles (first degree), or it may be that the alternate director provisions are already in some articles with which company presenters are familiar and so decided to include them despite their lack of inclusion in the Model Articles (third degree).

\footnotetext{
168 Moore (2014), p 709; Grier (2014), pp 1-30; Bennett (2013), p 1. For an argument to the contrary, see Hardman (2021).

169 See Bell (2003).

170 Margolis and Liebowitz (1998).

171 Margolis and Liebowitz (1998), p 18.
} 
In any event, it is highly possible that the continued use of alternate directors arises from path dependence rather than a determined desire by market participants to include such provision for a particular new company in the abstract of any previous market practice. However, whether the cause is path dependence or a determined attempt by the market to allow for alternate directors, the research outlined in this article demonstrates that provisions in respect of alternate directors are included in articles of association. Whether path dependent or not, following the introduction of the Model Articles, newly incorporated companies used some provisions of the old regime and rarely changed their constitutions. It could also be that this path dependence has faded over time, and that newer incorporated companies may not allow for alternate directors - this is worthy of further study.

Secondly, questions can be raised over the variables selected. It could be argued that they were not chosen in a systemic or holistic enough method. As a result, they may have missed some key elements of the Model Articles, or regular terms that are frequently added to the articles of association. Similarly, it could be argued that the study over-stated the importance of some variables: for example, appointment and removal of directors were listed as two variables, whereas it may have been more appropriate to merge them. It is submitted that the effect of this is minimised: throughout we have been clear that the purpose of this research was only to see whether market participants were diverging on specific variables, rather than extrapolating this to a more general statement about the Model Articles as a whole.

Thirdly, issues could be raised in respect of the coding of the variables. It is noted in Sect. 3 that a number of different divergences would all count as a divergence. Accordingly, if faced with a significant divergence, further research would be necessary to establish how the articles were diverging. However, this was not the case in any of the articles with multiple potentials for divergence, and so the rather crude binary leximetric coding is sufficient for out purposes.

Fourthly, it is questionable whether we can equate 'what people are doing in the market' with 'what the ideal majoritarian default is'. In particular, all the features that made default rules important may result in market participants being less keen to diverge from them. In addition to affecting the actual transaction required to achieve an efficient outcome, default rules can be 'sticky' — courts may hold parties to higher standards to opt out of them. ${ }^{172}$ Similarly, it has been stated that the Coase Theorem 'is not an empirical claim but is instead an analytic truth about what it means, under certain conditions, to act rationally'. ${ }^{173}$ Often, parties do not act rationally in this sense. ${ }^{174}$ It has been empirically demonstrated that default allocation of rights can factor in the bargaining positions taken by parties: Knetsch gave one group of test subjects pens and plotted their willingness to trade them for dollars,

\footnotetext{
172 Ayres (1999).

173 Coleman (1980), p 225.

174 Or rather, there are other ways that could be defined as acting rationally—see Cooter's 'Hobbes Theorem' whereby law is actively required to regulate bargaining to produce efficient results, Cooter (1982), pp 18-22. There is no other evidence that rational individuals will, ultimately, act in accordance with the Coase Theorem. See Regan (1972), p 431.
} 
and another group dollars and plotted their willingness to trade them for pens. He found that whether you started with pens or dollars dictated on the type of transaction you found acceptable for trade. ${ }^{175}$ In other words, it is not the case that (when swapping assets for each other) it is irrelevant who owns the asset in the first place.

Parties generally value amounts they have actually received more highly than they do opportunity cost income. ${ }^{176}$ Therefore parties may require more to sacrifice the benefits of default rules in their favour than they would pay for such benefits if the default rule were not in their favour. When negotiating a contract, each party's bargaining aims will vary depending on the default allocation of rules. Psychologically, there is a big difference between a negotiation whereby each party wishes to introduce 5 (different and not-overlapping) contractual terms, and one where one party wishes to introduce 10 contractual terms whereas the other party does not require any but is relaxed about the changes that the other party wishes to make. ${ }^{177}$ Accordingly, the selection of the Model Articles may influence what rules people select in the market.

Default rules apply unless opted out of, so are more likely to be utilised, so are more likely to appear in litigation, so parties are likely to have certainty as to their precise application. Conversely when bespoke drafting there is more possibility of an error-either in terms of meaning or accidental interaction with other default rules or express terms. ${ }^{178}$ There are also non-legal reasons for reticence to depart from default rules: too many deviations from the norm could mark the market participant as inexperienced, more contentious to trade with or an 'amateur' who can be exploited - any of which can lead to the breakdown of discussions in respect of forming a company. ${ }^{179}$ Similarly, a party may not wish to displace default rules if to do so would result in them having to disclose adverse information to avoid a 'price chip'-even if it risks a subsequent default. ${ }^{180}$ The full role for strategic bargaining is not yet fully analysed in the economic literature and default rules may play a bigger part than previously considered. ${ }^{181}$

These issues mean that all the factors that make default rules important enough to study also skew the market for that default rule. We cannot detect the effect of the default rule merely by observing it. As default rules always exist, ${ }^{182}$ we cannot ever verify whether a rule should be the majoritarian default rule using empirical analysis alone. In other words, we cannot say that just because market participants have not diverged from a particular variable that they definitively do not want to, and that had default rules been different then markets would have chosen differently. However, this does not matter for our purposes: the intention of this study was to establish

\footnotetext{
175 Knetsch (1992).

176 Kelman (1979), p 679_although this effect is questioned: Spitzer and Hoffman (1980).

177 For recent discussion of various psychological effects on bargaining, see Kohler (2013) and Kapakis,

Volkeman and Lampaki (2017).

178 Goetz and Scott (1985).

179 Bernstein (1993).

180 Ayres and Gertner (1989), pp 99-100.

181 Johnston (1990).

182 Kennedy (1993), p 89.
} 
whether market participants are using the Model Articles or diverging from them. The majority of variables are converged to- the reason for such convergence is outside the scope of this study.

Accordingly, there are some critiques which can be raised of the study outlined in this article, but these can each be answered. LoPucki has stated that legal empirical research needs be less statistically precise than other social sciences, on the grounds that often hunches are being verified. ${ }^{183}$ On this basis, the results of this paper stand on their own. Siems identified empirical work as a natural extension for originality in modern legal analysis. ${ }^{184}$ This research does not purport to be definitive, but it has made a key extension into understanding certain variables of the Model Articles in practice, and a methodology for evaluating how default rules are actually used.

\subsection{Further Study}

The methodology and outcomes of this article demonstrate a number of natural extensions to this research. The first extension is to increase the coding of articles beyond the coding undertaken in this article. There are five key areas where this expansion could take place:

1. By number. Larger sample groups lead to more statistically significant results. Accordingly, a future development is to code more companies and thus establish whether the results shown in this research are correct for a wider sample group, or even for all companies incorporated under the rules contained in the Companies Act 2006.

2. By variable. It may be possible to undertake a thematic analysis of all corporate law governance defaults and establish all variables that exist in such governance. Thus, an extension of the research would be to expand the number of variables analysed and thus obtain a more holistic answer to the efficiency of the Model Articles, rather than our limited study into a number of variables.

3. By coding. Binary coding was adopted because of its simplicity and because, functionally, a provision either converges or diverges from each relevant variable. However, a more complex coding system could be developed, to use those rejected in the design of this particular study, in particular either to include nonbinary variables (for example, under this research a partial convergence has to be starkly coded as a 0 or a 1 , whereas including a 0.5 option may provide a richer result) or by coding on different spectrums rather than convergence: for example, constructing a scale as to whether a governance item is 'shareholder friendly' (coded, say, 1), 'director friendly' (coded, say, -1) or 'neutral' (coded, say, 0) and thus constructing a scale that did not measure convergence but instead measured the corporate actor in whose interests the particular articles fared.

${ }^{183}$ LoPucki (2018).

184 Siems (2008a). 
4. By comparing across area and time. The sample groups measured companies incorporated within Scotland within specified time scales. It may therefore be the case that there is a lot of information to be gleaned by comparing regions against each other (does coding those incorporated with England and Wales or Northern Ireland for the same sample periods result in the same outcome?), and including a temporal aspect: do newer companies follow the same pattern? Does the time of year of incorporation make any difference? Does it increase or reduce any regional variances between them? Have regional differentials increased or decreased over time?

5. By more default rules. Articles of association are merely one source of default rules used within corporate law-it should be possible to examine other areas and other information (either publicly available or acquired by other primary methods such as surveys) to use quantitative leximetric methods to establish whether the default rule is correct or not.

The second extension is to expand the data leximetrically analysed. Companies House is a fascinating resource which is currently unexamined in legal study. Information such as shareholder details, ${ }^{185}$ 'person of significant control' details, ${ }^{186}$ security documents, ${ }^{187}$ insolvencies, ${ }^{188}$ number of directors ${ }^{189}$ and accounting reference dates $^{190}$ are publicly available. Quantitative analysis of all of these can be undertaken to establish relations between them.

The third extension is with the techniques applied to the raw data. As this article is a legal article rather than a statistical article, we have deliberately kept statistical elements as simple as possible. It may well be that utilising more sophisticated statistical techniques will result in more detailed results.

The fourth extension is to explore comparative analysis. This article has, of course, concentrated on UK private incorporated companies. There is analytical space to compare default rules between jurisdictions, in terms of both what rules are default rules, and what are not. ${ }^{191}$ Comparisons could then establish the extent to which any divergence can be compared between jurisdictions. This can further the analytical study of whether corporate law rules generally are converging, ${ }^{192}$ and the empirical approach taken to such matters. ${ }^{193}$

The analysis in the article involved establishing convergence or divergence from default rules established by the UK government. A fifth extension is to transcend

\footnotetext{
185 Companies Act 2006, s. 853F.

186 Small Business, Enterprise and Employment Act 2015, s. 81.

187 Companies Act 2006, s. 859A.

188 E.g. Insolvency Act 1986, Sch. B1, para. 46.

189 Companies Act 2006, s. 167.

190 Companies Act 2006, s. 392.

191 For example, it is argued in the UK sphere that more rules are mandatory than are frequently acknowledged-Moore (2014); and there are differences in this regard between the UK and the USCoffee (1989), p 1620.

192 Hansmann and Kraakman (2000).

193 E.g. Siems and Cabrelli (2015).
} 
such default rules: there is no reason why the analysis cannot be expanded to establish whether documents produced by trade bodies as 'market standard' documents are, in fact, complied with. For example, the Loan Market Association ('LMA') is the market standard for producing documents evidencing debt arrangements. ${ }^{194}$ LMA documents are a market standard starting point from which parties are free to commercially deviate. ${ }^{195}$ The empirical quantitative analysis deployed in this article can be extended beyond leximetrics to establish the likelihood that market participants deviate from certain LMA provisions. Other variables (for example, quantum of debt, extent of security, whether the finance is acquisition finance or not, the number of lenders) can also be coded to establish whether deviation from market standard is linked to any variables: and, in turn, whether it is correct to refer to a market standard or whether instead there are actually several markets. The extension of this methodology to over standard documents across markets is evident, with the only challenge being how to obtain from the market the actual documents that they are using.

A sixth extension of this research would be to move from corporate law default rules to default rules across a variety of legal disciplines. It may become possible to establish the degree to which market participants deviate from default rules across, for example, family law, employment law and contract law. Not only can the divergence of individual default rules be tested, but wider comparisons can be drawn: does one category of legal analysis experience more or less divergence than another? This can then lead on to exploration of voluntary interactions more generally: it may be the case that there are fewer deviations from the default rules in, say, family law because of higher barriers to contracting. Empirical examination of wider default rules can help establish this.

\section{Conclusion}

The move to the Companies Act 2006 took place in the UK over 10 years ago. It seems as if the UK government mostly met its aim when it picked the Model Articles: the majority of companies in our Sample converged to the identified variables of the Model Articles on incorporation. The exception to this was the framework for alternate directors, which companies mostly included despite not being included in the Model Articles. The majority of companies did not update their articles of association following their incorporation. In addition, the role of presenters in incorporating private companies is considerable. This was previously suspected, but this study presents empirical evidence towards this. Any future analysis of incorporations or constitutions of private companies should consider these results.

The study does not claim to be a holistic for the Model Articles across all companies, but does provide a clear result. This result is only applicable to the Sample, but it may be possible to extrapolate some of the outcomes of this study. More

\footnotetext{
194 See http://www.lma.eu.com/.

195 E.g. Saxton (2017); Johnson and Burgess (2017).
} 
importantly, this study provides a methodology that can be deployed in most situations. It also provides an empirical insight into an area for which there has been no current research.

Open Access This article is licensed under a Creative Commons Attribution 4.0 International License, which permits use, sharing, adaptation, distribution and reproduction in any medium or format, as long as you give appropriate credit to the original author(s) and the source, provide a link to the Creative Commons licence, and indicate if changes were made. The images or other third party material in this article are included in the article's Creative Commons licence, unless indicated otherwise in a credit line to the material. If material is not included in the article's Creative Commons licence and your intended use is not permitted by statutory regulation or exceeds the permitted use, you will need to obtain permission directly from the copyright holder. To view a copy of this licence, visit http://creativecommons.org/licen ses/by/4.0/.

\section{References}

Adams Z et al (2017) The CBR-LRI dataset: methods, properties and potential of leximetric coding of labour laws. Int J Comp Labour Law Ind Relat 33:59-91

Adler BE (1999) The questionable ascent of Hadley v Baxendale. Stanf Law Rev 51:1547-1589

Anderson $\mathrm{H}$ et al (2012) Investor and worker protection in Australia: a longitudinal analysis. Syd Law Rev 34:573-585

Ayres I (1999) Empire or residue: competing visions of the contractual cannon. Fla State Univ Law Rev 26(897):912

Ayres I, Gertner R (1989) Filling gaps in incomplete contracts: an economic theory of default rules. Yale Law J 99:87-130

Ayres I, Gertner R (1991) Strategic contractual inefficiency and the optimal choice of legal rules. Yale Law J 101(729):773

Ayres I, Gertner R (1999) Majoritarian v minoritarian defaults. Stanf Law Rev 51:1591-1613

Bainbridge SM (2008) The new corporate governance in theory and practice. OUP, Oxford

Bell J (2003) Path dependence and legal development. Tulane Law Rev 87(4):787-810

Bennett D (2013) Companies (reissue). Stair Society, Edinburgh

Berle AA, Means G (1967) The modern corporation and private property. Revised edn. Harcourt, Brace \& World Inc, New York

Bernstein L (1993) Social norms and default rules analysis. South Calif Interdiscip Law J 3(51):90

Berry E (2019) Limited partnership law and private equity: an instance of legislative capture? J Corp Law Stud 19(1):105-135

Braendle UC (2006) Shareholder protection in the USA and Germany-'Law and finance' revisited. German Law J 7(3):257-278

Cheffins BR (2008) Company law theory, structure and operations. OUP, Oxford

Cheung R (2008) The use of statutory unanimous shareholder agreements and entrenched articles in reserving minority shareholders' rights: a comparative analysis. Co Lawyer 29(8):234-241

Chiu IHY (2009) The role of a company's constitution in corporate governance. J Bus Law 7:697-726

Coase RH (1960) The problem of social cost. J Law Econ 3:1-44

Coffee JC (1989) Mandatory/enabling balance in corporate law: an essay on the judicial role. Columbia Law Rev 89:1618-1691

Coleman JL (1980) Efficiency, exchange, and auction: philosophic aspects of the economic approach to law. Calif Law Rev 68(2):221-249

Cools S (2006) The real difference in corporate law between the United States and Continental Europe: distribution of powers. Del J Corp Law 30(3):697-766

Cooter RD (1982) The cost of Coase. J Leg Stud 11:1-33

Cooter RD, Ginsburg T (2003) Leximetrics: why the same laws are longer in some countries than others. http://ssrn.com/abstract=456520. Accessed 15 Apr 2021 
Cosh A, Hughes A (1994) Size, financial structure and profitability: UK companie in the, 1980. In: Hughes A, Story DJ (eds) Finance and the small firm. Routledge, London, pp 18-63

Davies PL, Worthington S (2016) Gower: principles of modern company law. Sweet \& Maxwell, London

Demetz H (1972) When does the rule of liability matter? J Leg Stud 1:13-28

Department for Business, Energy and Industrial Strategy (2020) Corporate transparency and register reform: Government responses to the consultation on options to enhance the role of Companies House and increase the transparency of UK corporate entities. https://assets.publishing.service. gov.uk/government/uploads/system/uploads/attachment_data/file/925059/corporate-transparen cy-register-reform-government-response.pdf. Accessed 22 Apr 2021

Department for Business, Innovation and Skills (2011) Companies Act 2006 final implementationchanges to constitutional documents, including Model Articles: a summary of what the new approach means. https://web.archive.org/web/20111206085005/http://www.bis.gov.uk/files/file5 3041.pdf. Accessed 15 Apr 2021

Ellickson RC (1989) The case for Coase and against 'coaseanism'. Yale Law J 99:611-631

Ellickson RC (1991) Order without law: how neighbours settle disputes. Harvard University Press, Harvard

Esser IM, MacNeil I, Chalaczkiewicz K (2018) Engaging stakeholders in the UK in corporate decision making through strategic reporting: an empirical study of FTSE 100 companies. Eur Bus Law Rev 29(5):729-772

Fagernäs S, Sarkar P, Singh A (2008) Legal origin, shareholder protection and the stock market: new challenges from time series analysis. In: Gugler K, Yurtoglu BB (eds) The economics of corporate governance and mergers. Edward Elgar, Cheltenham, pp 20-53

Feldman AM (1998) Pareto optimality. In: Newman P (ed) The new Palgrave dictionary of economics and the law, vol 3. Palgrave MacMillan, London, pp 8-12

Ferran E (2019) Revisiting legal capital. EBOR 20:521-545

Freeman M, Pearson R, Taylor J (2013) Law, politics and the governance of English and Scottish joint-stock companies. Bus Hist 55:636-652

Goetz CJ, Scott RE (1985) The limits of expanded choice: an analysis of the interactions between express and implied contract terms. Calif Law Rev 73(2):261-322

Grier N (2014) Company law, 4th edn. Thomson Reuters, Edinburgh

Hansmann H, Kraakman R (2000) The end of history for corporate law. Georget Law J 89:439-468

Hardman J (2017) Some legal determinants of external finance in Scotland: a response to Lord Hodge. Edinb Law Rev 21(1):30-54

Hardman J (2018) The moral hazard of limited liability: an empirical Scottish study. Nottm Insolv Bus Law eJournal 6:30-77

Hardman J (2020a) The Companies Act 2006: it's time to complete the transition. Co Lawyer 41:93-97

Hardman J (2020b) Leximetric coding of private companies incorporated in Scotland in October 2009. DOI: https://doi.org/10.7488/ds/2805. Accessed 22 Apr 2021

Hardman J (2021) Further legal determinants of external finance in Scotland: an intra-UK market for incorporation? Edinb Law Rev 25(2):192-214

Haslemann R, Pistor K, Vig V (2010) How law affects lending. Rev Financ Stud 23(2):549-580

Howley S, Bateman P (2007) Legislative comment Companies Act 2006: an overview: part 1. Co Law News1 10:1-11

Hsiung B (1999) Sailing towards the brave new world of zero transaction costs. Eur J Law Econ 8:153-169

Huang F (2017) Dual class shares around the top global financial centres. J Bus Law 15:137-154

Department of Trade and Industry (2007) Implementation of the Companies Act 2006: a consultative document. URN 07/666

Johnson K, Burgess D (2017) LMA standard forms and lenders' standard terms of business. J Int Bank Financ Law 32(9):586-587

Johnston JS (1990) Strategic bargaining and the economic theory of contract default rules. Yale Law J 100:615-664

Kapakis I, Volkeman R, Lampaki A (2017) Mind the first step: the intrapersonal effects of affect on the decision to initiate negotiations under bargaining asymmetry. Front Psychol 2:8-25

Kelman M (1979) Consumption theory, production theory, and ideology in the Coase Theorem. South Calif Law Rev 52(3):669-698 
Kennedy D (1993) Sexy dressing etc. Essays in the power and politics of cultural identity. Harvard University Press, Harvard

Knetsch JL (1992) Preferences and nonreversibility of indifference curves. J Econ Behav Organ 17:131-139

Kohler S (2013) Envy can promote more equal division in alternating-offer bargaining. J Neurosci Psychol Econ 6:31-41

Kraakman R et al (2017) The anatomy of corporate law. OUP, Oxford

La Porta R et al (1997) Legal determinants of external finance. J Finance 52(3):1131-1150

La Porta R et al (1998) Law and finance. J Polit Econ 106(6):1113-1155

Lele PP, Siems MM (2007) Shareholder protection: a leximetric approach. J Corp Law Stud 7:17-50

Lin YH, Chang YC (2018) An empirical study of corporate default rules and menus in China, Hong Kong, and Taiwan. J Empir Leg Stud 15(4):875-915

LoPucki LM (2018) A rule-based method for comparing corporate laws. Notre Dame Law Rev 94:263-296

Margolis SE, Liebowitz SJ (1998) Path dependence. In: Newman P (ed) The new Palgrave dictionary of economics and the law, vol 3. Palgrave Macmillan, London, pp 17-23

Milman D (2017) Regulating close companies in corporate law: towards a more formal recognition? Common Law World Rev 46(3):198-215

Moore MT (2014) Private ordering and public policy: the paradoxical foundations of corporate contractarianism. Oxf J Leg Stud 34:693-728

Morse G et al (2019) Palmer's company law. Relese 69, Sweet \& Maxwell, London

New Zealand Law Commission (1989) Company law: reform and restatement. R9

Nyombi C (2014) The gradual erosion of the ultra vires doctrine in English company law. Int J Law Manag 56(5):347-362

Omar PJ (2004) Powers, purposes and objects: the protracted demise of the ultra vires rule. Bond Law Rev 16:93-116

Omar PJ (2009) In the wake of the Companies Act 2006: an assessment of the potential impact of reforms to company law. ICCLR 20(2):44-55

Pistor K (2000) Patterns of legal change: shareholder protection and creditor rights in transition economies. EBOR 1(1):59-107

Polak K (1986) Company law_class rights. Camb Law J 45(3):399-401

Posner EA (2003) Economic analysis of the law after three decades: success or failure? Yale Law J 112:829-880

Posner R (2014) Economic analysis of the law, 9th edn. Wolters Kluwer, New York

Regan DH (1972) The problem of social cost revisited. J Law Econ 15:427-437

Riley CA (2010) The not-so-dynamic quality of corporate law: a UK perspective on Hansmann's 'Corporation and contract'. King's Law J 21(3):469-494

Saxton L (2017) The new LMA fronted agreements. J Int Bank Financ Law 10:653

Schlag P (2013) Coase minus the Coase theory-some problems with Chicago transaction costs analysis. Iowa Law Rev 99(1):175-222

Schwab S (1988) A Coasean experiment on contract presumptions. J Legal Stud 17(2):237-268

Schwab S (1989) Coase defends Coase: why lawyers listen and economists do not. Mich Law Rev 87(6):1171-1198

Siems M (2008a) Legal originality. Oxf J Leg Stud 28:147-164

Siems M (2008b) Shareholder protection around the world (Leximetric II). Del J Corp Law 33:111-147

Siems M (2010) Convergence in corporate governance: a leximetric approach. J Corp Law 35:729-765

Siems M, Cabrelli D (2015) Convergence, legal origins, and transplants in comparative corporate law: a case-based and quantitative analysis. Am J Comp Law 63:109-153

Spamann H (2010) The 'Antidirector Rights Index' revisited. Rev Financ Stud 23(2):467-487

Spitzer M, Hoffman E (1980) A reply to consumption theory, production theory, and ideology in the Coase Theorem. South Calif Law Rev 53(4):1187-1215

Watson S (2011) The significance of the source of the powers of boards of directors in UK company law. J Bus Law 9:597-613

Publisher's Note Springer Nature remains neutral with regard to jurisdictional claims in published maps and institutional affiliations. 